Article

\title{
Comparison between a Traditional (Horse Manure) and a Non-Conventional (Cork Powder) Organic Residue in the Uptake of Potentially Toxic Elements by Lettuce in Contaminated Soils
}

\author{
Inês Moreira, Inês Leitão, Miguel P. Mourato * ${ }^{*}$ and Luisa L. Martins
}

Citation: Moreira, I.; Leitão, I.; Mourato, M.P.; Martins, L.L. Comparison between a Traditional (Horse Manure) and a

Non-Conventional (Cork Powder) Organic Residue in the Uptake of Potentially Toxic Elements by Lettuce in Contaminated Soils. Environments 2021, 8, 45. https://doi.org/10.3390/ environments 8050045

Academic Editor:

Gianniantonio Petruzzelli

Received: 8 April 2021

Accepted: 13 May 2021

Published: 18 May 2021

Publisher's Note: MDPI stays neutral with regard to jurisdictional claims in published maps and institutional affiliations.

Copyright: (c) 2021 by the authors. Licensee MDPI, Basel, Switzerland. This article is an open access article distributed under the terms and conditions of the Creative Commons Attribution (CC BY) license (https:// creativecommons.org/licenses/by/ $4.0 /)$.
LEAF, Instituto Superior de Agronomia, Universidade de Lisboa, 1349-017 Lisboa, Portugal; ines.nmoreira@gmail.com (I.M.); inesibleitao@gmail.com (I.L.); luisalouro@isa.ulisboa.pt (L.L.M.)

* Correspondence: mmourato@isa.ulisboa.pt

\begin{abstract}
The use of natural organic correctives is a current agricultural practice that may have advantages for the production of plants in contaminated soils. Cork powder is a natural sub-product of the cork industry that has several potential benefits compared to more commonly used soil amendments. In this work, an evaluation was performed of the use of cork powder (a non-conventional organic residue) and horse manure (traditionally used in agriculture) to control the availability of potentially toxic elements in artificially contaminated soils. Four concentrations were used for each element: $\mathrm{Cr}$ (100 to $\left.800 \mathrm{mg} \mathrm{kg}^{-1}\right)$, $\mathrm{Ni}\left(37.5\right.$ to $\left.300 \mathrm{mg} \mathrm{kg}^{-1}\right), \mathrm{Zn}$ (150 to $\left.1200 \mathrm{mg} \mathrm{kg}^{-1}\right), \mathrm{Cd}\left(1.5\right.$ to $12 \mathrm{mg} \mathrm{kg}^{-1}$ ) and $\mathrm{Pb}\left(150\right.$ to $\left.1200 \mathrm{mg} \mathrm{kg}^{-1}\right)$. The accumulation of these elements in lettuce plants grown in pots under controlled conditions was evaluated. With the exception of $\mathrm{Cd}$, no significant differences were detected in the absorption of the different elements by lettuce plants at the studied amounts of correctives applied ( $1 \%$ for cork powder and $0.5 \%$ for horse manure). Cadmium was the element that accumulated most in lettuce. Cork powder was shown to be less effective than horse manure in controlling the bioavailability of these elements in the soil. Further tests with chemically modified cork products could improve its efficiency.
\end{abstract}

Keywords: cadmium; chromium; lead; nickel; zinc; cork; horse manure; element accumulation; lettuce

\section{Introduction}

The contamination of vegetables by potentially toxic elements (PTE), either essential or non-essential, is a widespread problem that spans different scientific areas like those related to the environment, agronomy, food production, and public health. Soil contamination with PTE results, in most cases, from anthropogenic causes like agricultural, mining and industrial activity, atmospheric deposition, waste water, domestic effluents, and the use of poor quality corrective materials [1].

Although contamination has been greatly reduced in most developed countries, many soils can still contain high levels of contaminants resulting from previous anthropogenic activities and, in many countries, this contamination remains [2,3]. The contamination of vegetables with PTE can thus occur, mainly, due to their presence of toxic levels of certain PTE in soils, irrigation water, and air [4,5].

While $\mathrm{Cd}, \mathrm{Cr}$, and $\mathrm{Pb}$ are non-essential elements for plants, $\mathrm{Ni}$ and $\mathrm{Zn}$ are essential micronutrients, but all can be toxic above critical concentrations [5].

Chromium is one of the most abundant metals in the earth's crust and usual mass fractions in soils range from 0.1 to $0.3 \mathrm{mg} \mathrm{kg}^{-1}$ [6]. Both Portuguese and Canadian regulations define a limit of $67 \mathrm{mg} \mathrm{kg}^{-1}$ for the total $\mathrm{Cr}$ content in agricultural soils $[7,8]$. While $\mathrm{Cr}$ has several oxidation states, the most common are $\mathrm{Cr}^{3+}$ and $\mathrm{Cr}^{6+}$ which can interconvert depending on redox conditions, being $\mathrm{Cr}^{6+}$ the most toxic form [9]. The form 
$\mathrm{Cr}^{3+}$ is less toxic and predominates in most soils, presenting low mobility and occurring mostly linked to organic matter [10].

Nickel is an essential element for plants where it is usually found in low mass fraction in the range $0.05-10 \mathrm{mg} \mathrm{kg}^{-1}$ dry mass (DM), but it can reach higher mass fractions in plants growing in Ni contaminated soils leading to toxicity symptoms [11,12]. In soils, normal $\mathrm{Ni}$ values are reported to range between 0.5 and $10 \mathrm{mg} \mathrm{kg}^{-1}$ [13] and in Portuguese and Canadian regulations the limit for $\mathrm{Ni}$ in agricultural soils is defined as $37 \mathrm{mg} \mathrm{kg}^{-1}[7,8]$.

Zinc is also an essential element and is present in soils in mass fractions between 10 and $300 \mathrm{mg} \mathrm{kg}^{-1}$ with an average of around $55 \mathrm{mg} \mathrm{kg}^{-1}$ [14]. Although deficiency symptoms are usually a problem [15], toxic effects have also been reported [16]. Portuguese and Canadian regulations limit the amount of $\mathrm{Zn}$ in agricultural soils to $290 \mathrm{mg} \mathrm{kg}^{-1}[7,8]$.

Cadmium mass fractions in uncontaminated soils vary between 0.02 and $2.0 \mathrm{mg}$ $\mathrm{Cd} \mathrm{kg}^{-1}$ or higher in sedimentary rock soils $\left(0.3\right.$ to $\left.15 \mathrm{mg} \mathrm{Cd} \mathrm{kg}^{-1}\right)$ [1]. Several countries have regulated the maximum $\mathrm{Cd}$ mass fractions in soils and, for example, they must have levels below $1 \mathrm{mg} \mathrm{Cd} \mathrm{kg}^{-1}$ in agricultural soil according to both Portuguese and Canadian regulations $[7,8]$. While $\mathrm{Cd}$ is relatively available for absorption by the plant, its bioavailability and mobility is highly dependent on soil properties like $\mathrm{pH}$ and organic matter [17]. Due to its high mobility Cd can easily accumulate inside the plants at toxic levels and induce different defence responses [18].

Lead is a widespread pollutant that can be toxic for animals and plants despite its relatively low mobility from soil to plants $[19,20]$. Although the use and emissions of $\mathrm{Pb}$ has been declining in recent years it can still present a severe environmental problem [21]. In soils used for agriculture, Portuguese and Canadian regulations define a maximum mass fraction of $\mathrm{Pb}$ of $45 \mathrm{mg} \mathrm{kg}^{-1}[7,8]$.

Contaminants, like the PTE described, cannot be easily removed from the soil. However, under certain conditions, soil amendments (like organic correctives) can be used to reduce the availability of PTE by changing soil $\mathrm{pH}$ and increasing the number of PTE binding sites [22]. The use of natural organic amendments, like manure, is a current practice that can have advantages for the production of plants in contaminated soils [23,24]. Different soil amendments have been used to improve soil quality and reduce PTE toxicity, like paper industry wastes [25], manure-based biochars and composts [26], or different type of polymers [27]. Although there are several reports on the effects of soil amendments to reduce PTE toxicity, there is still a lack of knowledge of the proper uptake mechanisms and of the use of environmentally friendly subproducts of several activities, like the cork industry.

Cork is an important economic activity in several Mediterranean countries and cork subproducts have been studied as absorbent materials for different pollutants, mainly in water [28]. However, to the best of our knowledge, there have been no reported studies on the capacity of cork subproducts to absorb PTE from contaminated soils.

The main objective of the present work was to evaluate the potential use of two natural organic amendments (a conventional one, horse manure and a non-conventional one, cork powder) on the capacity to reduce the availability (and, consequently, the uptake and toxicity) of five PTE ( $\mathrm{Cd}, \mathrm{Cr}, \mathrm{Pb}, \mathrm{Ni}$, and $\mathrm{Zn}$ ) in artificially contaminated soils for lettuce plants. While horse manure is traditionally used in agriculture, there are no known reports on the application of cork powder as an amendment. Lettuce was chosen as it is a widely consumed vegetable around the world and is also a model species reported to be highly tolerant to PTE [29].

\section{Materials and Methods}

\subsection{Soil Contamination, Soil Amendment and Plant Production}

In this work, experiments were performed with Lactuca sativa L. plants, variety capitata, cultivar " 4 seasons" (a popular cultivar used in several countries). The soil used in the pot experiments ( $4 \mathrm{~kg}$ pots) was fully characterized (Table 1 ) and individually contaminated with each PTE $(\mathrm{Cd}, \mathrm{Cr}, \mathrm{Pb}, \mathrm{Ni}$ and $\mathrm{Zn})$ at 4 different mass fractions, plus control 
(Table 2) and left to stabilize for 6 months before use (maintaining 60\% water saturation). The PTE were added to the soils as water solutions of appropriate concentrations using the salts described in Table 2. The mass fractions were chosen based on the values listed in Portuguese legislation regarding the use of sewage sludge in agricultural soils [30] and correspond to multiples of the maximum levels of each PTE allowed in the soil at the appropriate $\mathrm{pH}(0.5 \times, 1 \times, 2 \times, 4 \times)$.

Table 1. Soil characterization.

\begin{tabular}{|c|c|c|}
\hline Parameter & & Value \\
\hline Conductivity $(1: 2)\left(\mathrm{mS} \mathrm{cm}^{-1}\right)$ & & $0.10 \pm 0.02$ \\
\hline $\mathrm{pH}\left(\mathrm{H}_{2} \mathrm{O}\right)(1: 2.5)$ & & $6.9 \pm 0.1$ \\
\hline Organic matter $\left(\mathrm{g} \mathrm{kg}^{-1}\right)$ & & $13.6 \pm 0.2$ \\
\hline Extractable $\mathrm{P}\left(\mathrm{mg} \mathrm{kg}^{-1}\right)$ & & $73.8 \pm 5.2$ \\
\hline Extractable $\mathrm{K}\left(\mathrm{mg} \mathrm{kg}^{-1}\right)$ & & $57.5 \pm 4.4$ \\
\hline Ammoniacal nitrogen $\left(\mathrm{N}-\mathrm{NH}_{4}\right)\left(\mathrm{mg} \mathrm{kg}^{-1}\right)$ & & $2.35 \pm 0.15$ \\
\hline Nitric nitrogen $\left(\mathrm{N}-\mathrm{NO}_{3}\right)\left(\mathrm{mg} \mathrm{kg}^{-1}\right)$ & & $<1.0$ \\
\hline \multirow{4}{*}{ Extractable micronutrients $\left(\mathrm{mg} \mathrm{kg}^{-1}\right)$} & $\mathrm{Fe}$ & $31.1 \pm 1.9$ \\
\hline & $\mathrm{Cu}$ & $4.8 \pm 0.2$ \\
\hline & $\mathrm{Zn}$ & $1.4 \pm 0.1$ \\
\hline & Mn & $35.2 \pm 2.0$ \\
\hline
\end{tabular}

Table 2. PTE mass fractions used in the pot experiment.

\begin{tabular}{cccccccc}
\hline & PTE & \multicolumn{7}{c}{ Mass Fractions $\left.\mathbf{( m g ~ k g} \mathbf{~ k g}^{-\mathbf{1}}\right)$} & Applied Form \\
\hline \multirow{2}{*}{ non } & $\mathrm{Cd}$ & 0 & 1.5 & 3 & 6 & 12 & $\mathrm{CdCl}_{2} \cdot 5 / 2 \mathrm{H}_{2} \mathrm{O}$ \\
essential & $\mathrm{Cr}$ & 0 & 100 & 200 & 400 & 800 & $\mathrm{CrCl}_{3} \cdot 6 \mathrm{H}_{2} \mathrm{O}$ \\
& $\mathrm{Pb}$ & 0 & 150 & 300 & 600 & 1200 & $\left.\mathrm{~Pb}^{2} \mathrm{NO}_{3}\right)_{2}$ \\
\hline \multirow{2}{*}{ essential } & $\mathrm{Ni}$ & 0 & 37.5 & 75 & 150 & 300 & $\mathrm{NiCl}_{2} \cdot 6 \mathrm{H}_{2} \mathrm{O}$ \\
& $\mathrm{Zn}$ & 0 & 150 & 300 & 600 & 1200 & $\mathrm{ZnSO}_{4} .7 \mathrm{H}_{2} \mathrm{O}$ \\
\hline
\end{tabular}

For each PTE, 3 treatments were performed: S-control, with no organic amendment; SC - soil with added cork powder (1\%); and SE-soil with added horse manure $(0.5 \%)$. The percentage of each amendment was selected in order to obtain the same amount of organic matter added to the soil. Each of these modalities and each PTE was performed in triplicate (3 different pots, with one plant per pot) and so, for the 5 PTE mass fractions used, a total of 45 pots were used per PTE. A basal fertilization (N, P, and K) was performed prior to plants being placed in the pots and based on previous soil analysis $\left(0.15 \mathrm{~g} \mathrm{~N} \mathrm{~kg}^{-1}\right.$ soil added as $\mathrm{NH}_{4} \mathrm{NO}_{3}, 0.033 \mathrm{~g} \mathrm{P} \mathrm{kg}^{-1}$ soil added as $\mathrm{KH}_{2} \mathrm{PO}_{4}$ and $0.125 \mathrm{~g} \mathrm{~K} \mathrm{~kg}^{-1}$ soil added as $\mathrm{K}_{2} \mathrm{SO}_{4}$ ).

Lettuce seeds were germinated in peat substrate and after 2 weeks plants were planted in each pot. The pots were kept in a greenhouse, randomly distributed, with periodic rotation. Plant material (lettuce leaves) were collected and analyzed after 80 days of growth.

\subsection{Plant Determinations}

Lettuce leaves were collected and immediately weighed to obtain the fresh weight (FW). Samples were washed with deionized water and dried at $70{ }^{\circ} \mathrm{C}$ until constant weight to obtain the dry weight (DW). Subsamples of the dried material with $0.5 \mathrm{~g}$ were digested with a mixture of $3 \mathrm{~mL}$ concentrated $\mathrm{HNO}_{3}$ with $10 \mathrm{~mL}$ concentrated $\mathrm{HCl}$ in a digestion block (DigiPREP MS) for $120 \mathrm{~min}$. The solutions were then analyzed for $\mathrm{Cd}, \mathrm{Cr}, \mathrm{Pb}, \mathrm{Ni}$ and Zn by ICP-OES (Thermo Scientific iCAP 7200 duo) as described previously [31].

\subsection{Quality Assurance}

All determinations were performed in triplicate, always including blanks. With each digestion, a certified reference material (CRM) was always analyzed (Wepal lettuce IPE 776). 
Deviations between measured and CRM values were always below $10 \%$. All calibrations curves had $\mathrm{R}^{2}>0.98$. Calculated limits of quantification $(\mathrm{mg} / \mathrm{kg})$ were: $\mathrm{Cr}-1.0 ; \mathrm{Ni}-1.5$; $\mathrm{Zn}-1.0 ; \mathrm{Cd}-0.05$; and $\mathrm{Pb}-0.2$.

\subsection{Transfer Factor (TF)}

The transfer factor measures the fraction of the PTE that is absorbed by the plant in relation to the total in soil and is calculated using the following expression:

$$
\mathrm{TF}=\frac{\mathrm{C}_{\mathrm{P}}}{\mathrm{C}_{\mathrm{S}}}
$$

where $C_{p}$ is the PTE mass fraction in lettuce leaves $\left(\mathrm{mg} \mathrm{kg}^{-1} \mathrm{DW}\right)$ and $\mathrm{C}_{\mathrm{s}}$ is the PTE mass fraction in the soil $\left(\mathrm{mg} \mathrm{kg}^{-1}\right)$.

\subsection{Tolerance Index (TI)}

The tolerance index [32] measures the fresh weight of lettuce shoots growing in contaminated soil in relation to the fresh weight of lettuce shoots growing in non-contaminated (control) soil, using the following expression:

$$
\mathrm{TI}=\frac{\mathrm{FW}_{\mathrm{M}}}{\mathrm{FW}_{\mathrm{Ctr}}} \times 100
$$

where $\mathrm{FW}_{\mathrm{M}}$ is the fresh weight of lettuce aerial parts (g) growing in contaminated soil and $\mathrm{FW}_{\mathrm{Ctr}}$ is the fresh weight of lettuce aerial parts $(\mathrm{g})$ growing in non-contaminated soil (control).

\subsection{Statistical Treatment}

The results were analyzed with a one-factor analysis of variance (ANOVA) performed with the SPSS 20.0 (SPSS Inc., Chicago, IL, USA) software and the Tukey test was used to determine significant differences between the means $(p<0.05)$ and was carried out to compare PTE contents between control and contaminated plants and with and without added organic amendments. In the figures, different lowercase letters reflect significant differences between treatments (S-control coil, SC-soil with cork subproducts, and SE-soil with horse manure) for the same PTE mass fraction while different uppercase letters reflect significant differences between PTE mass fractions for the same treatment. The experimental data obtained was classified using a partitioning clustering method (partitioning around medoids; PAM) [33] with three clusters, allowing to differentiate individuals based on two classes: PTE mass fraction in the soil and treatment (S, SC, SE). This was performed using a correlation matrix with six normalized variables (fresh weight of shoots, PTE mass fraction in the shoots, PTE mass fraction in the soil, extractable PTE in soil, soil $\mathrm{pH}$, and soil organic matter), using the R studio software (Version 1.0.136, RStudio, Inc., Boston, MA, USA).

\section{Results and Discussion}

\subsection{PTE Uptake Behavior in Lettuce}

The contents of all PTE under study $(\mathrm{Cd}, \mathrm{Cr}, \mathrm{Ni}, \mathrm{Pb}$ and $\mathrm{Zn}$ ) in the plant increased with the respective mass fraction in soil, although the accumulation behavior can be explained by different models. The accumulation curves of the PTE in lettuce are shown in Figure 1a-e. The parameters of the adjusted models for each curve are presented in Table 3. 
OS ISC $\triangle S E$

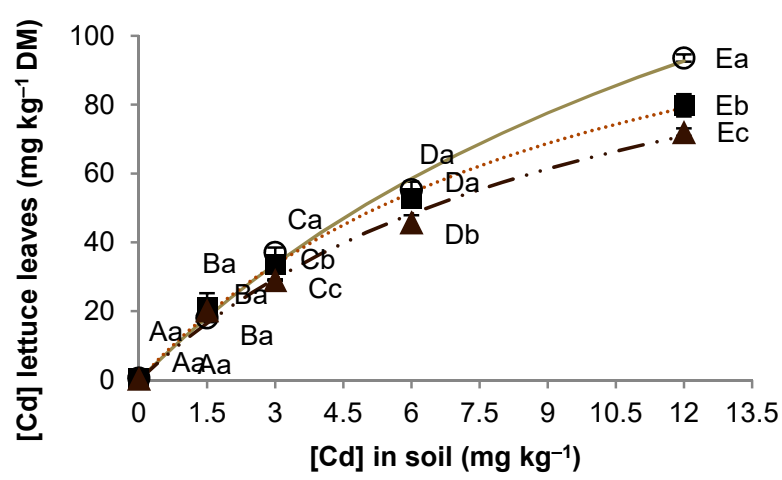

(a)

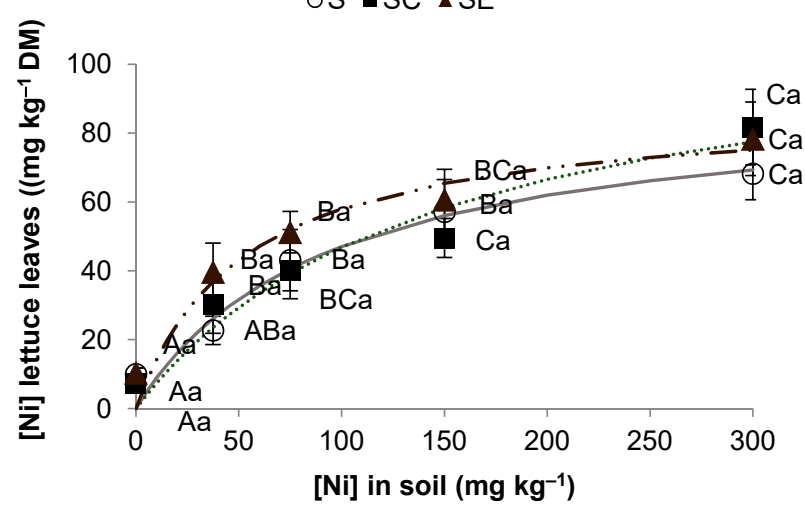

(c)

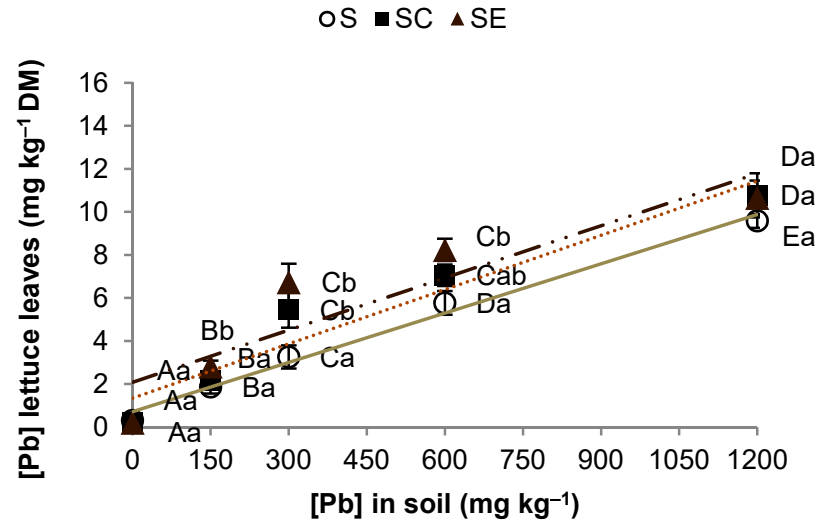

(b)

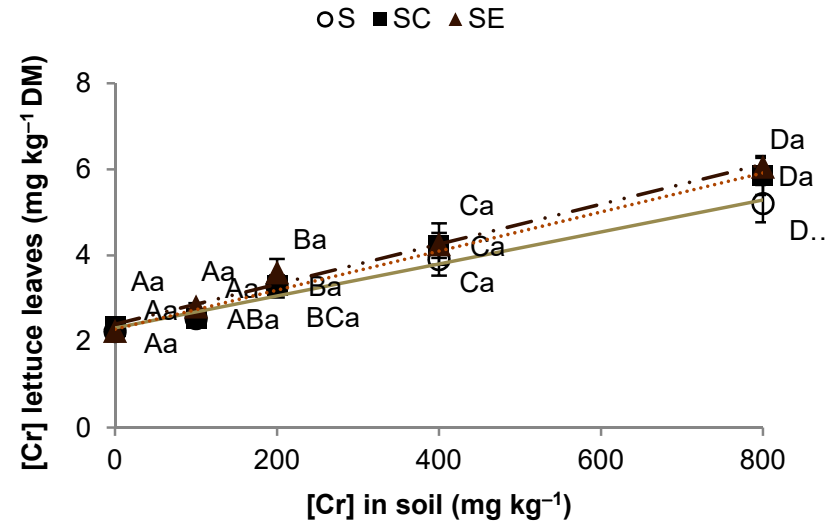

(d)

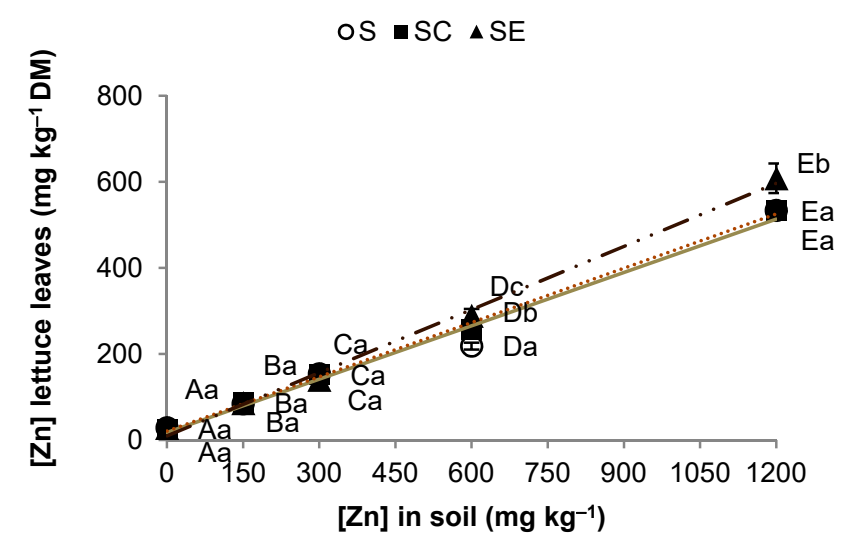

(e)

Figure 1. Accumulation curves of PTE content in lettuce leaves of plants growing in non-amended soil (S), soil amended with cork powder (SC) and soil amended with horse manure (SE): (a) $\mathrm{Cd}$; (b) $\mathrm{Pb}$; (c) Ni; (d) $\mathrm{Cr}$; (e) $\mathrm{Zn}$. 
Table 3. Parameters of the models fitted to the PTE accumulation curves.

\begin{tabular}{|c|c|c|c|c|}
\hline \multirow[b]{2}{*}{ PTE } & \multirow[b]{2}{*}{ Treatment } & \multicolumn{3}{|c|}{ Hyperbolic Model } \\
\hline & & $\mathrm{C}_{\max }$ & $K_{M}$ & $\mathbf{R}^{2}$ \\
\hline \multirow{3}{*}{$\mathrm{Cd}$} & $\mathrm{S}$ & $222.3 \pm 35.4$ & $16.8 \pm 4.0$ & 0.9955 \\
\hline & SC & $143.9 \pm 9.9$ & $9.8 \pm 1.2$ & 0.9980 \\
\hline & SE & $133.5 \pm 18.4$ & $10.6 \pm 2.5$ & 0.9926 \\
\hline \multirow{3}{*}{$\mathrm{Ni}$} & $\mathrm{S}$ & $90.8 \pm 15.2$ & $93.1 \pm 39.7$ & 0.9476 \\
\hline & SC & $115.2 \pm 28.4$ & $146.0 \pm 77.3$ & 0.9351 \\
\hline & SE & $88.2 \pm 11.7$ & $52.1 \pm 22.5$ & 0.9419 \\
\hline & & \multicolumn{3}{|c|}{ Linear model } \\
\hline PTE & Treatment & m & b & $\mathbf{R}^{2}$ \\
\hline \multirow{3}{*}{$\mathrm{Cr}$} & $\mathrm{S}$ & $0.0037 \pm 0.0003$ & $2.313 \pm 0.132$ & 0.9826 \\
\hline & SC & $0.0045 \pm 0.0003$ & $2.288 \pm 0.104$ & 0.9906 \\
\hline & SE & $0.0046 \pm 0.0003$ & $2.404 \pm 0.128$ & 0.9877 \\
\hline \multirow{3}{*}{$\mathrm{Pb}$} & $S$ & $0.0076 \pm 0.0005$ & $0.719 \pm 0.288$ & 0.9897 \\
\hline & SC & $0.0084 \pm 0.0014$ & $1.349 \pm 0.845$ & 0.9282 \\
\hline & SE & $0.0081 \pm 0.0021$ & $2.087 \pm 1.269$ & 0.8343 \\
\hline \multirow{3}{*}{$\mathrm{Zn}$} & S & $0.41 \pm 0.03$ & $17.6 \pm 20.4$ & 0.9812 \\
\hline & SC & $0.42 \pm 0.01$ & $21.1 \pm 7.2$ & 0.9977 \\
\hline & SE & $0.49 \pm 0.02$ & $9.9 \pm 11.7$ & 0.9955 \\
\hline
\end{tabular}

The accumulation curves describe the content in the plant as a function of the mass fractions of PTE present in the soil, being valid for the tested range. The accumulation of $\mathrm{Cd}$ and $\mathrm{Ni}$ is best described by a hyperbolic model while the accumulation of $\mathrm{Cr}, \mathrm{Pb}$, and $\mathrm{Zn}$ is best described by a linear model.

In the hyperbolic model, the accumulation tends to a plateau, after an initial increase the uptake tends to stabilize for higher mass fractions of the PTE in the soil. In the linear models there is a direct proportionality between the values accumulated in the plant and the values present in the soil.

The addition of the organic amendments (SC and SE) did not change the uptake behavior but led to significant decreases in the uptake of $\mathrm{Cd}$. For the other PTE no differences in the uptake were observed.

The hyperbolic model was the one that best described the behavior of $\mathrm{Cd}$ and $\mathrm{Ni}$ uptake by lettuce as a function of the element mass fraction in soil (Figure 1a,c). This means that there is greater $\mathrm{Cd}$ and $\mathrm{Ni}$ uptake for lower element levels in the soil and, as these levels increase, the rate of PTE taken up by the plant is reduced tending towards a saturation value, which is given by the constant $C_{\max }$, obtained for higher mass fractions of PTE in the medium. This is probably due to the saturation of the root absorbing power at higher element mass fractions, which can be related to a defence mechanism to avoid the uptake of an excess amount of $\mathrm{Cd}$ and $\mathrm{Ni}$. While $\mathrm{Ni}$ is an essential element for plants and $\mathrm{Cd}$ is non-essential, $\mathrm{Ni}$ is required only in low mass fractions for adequate plant functions [12].

The $C d-C_{\text {máx }}$ coefficient, representing the predicted maximum mass fraction level of Cd absorbed by the plant, is higher in the control, S (222.3), compared to SC (149.9) and $S E$ (133.5). $C_{\max }$ has a lower value in the modalities in which organic residues were added to the soil, indicating that the organic correctives had a beneficial effect, SE being more effective than SC. The Ni- $\mathrm{C}_{\text {máx }}$ coefficient was 90.8 for the control (S), 115.2 with cork powder (SC) and 88.1 with manure (SE). No beneficial effect was evident with SC in reducing the accumulation of $\mathrm{Ni}$ in the plant, and there is only a very small effect in $\mathrm{SE}$. We can conclude that the presence of these organic correctives had no significant influence on the accumulation of $\mathrm{Ni}$ in lettuce.

Other studies have reported different behavior, but under different experimental conditions. Stritsis and Claassen [34] evaluated the Cd uptake kinetics on 4 different species (maize, sunflower, spinach, and flax) and noticed a linear relationship in Cd uptake, but their study was in nutrient solution, where all the $\mathrm{Cd}$ is readily available for uptake. 
This difference in experimental conditions and the use of different plants could explain the difference in behavior as in a study with lettuce in a field experiment, Chen, et al. [35] observed a behavior similar to our study, and the authors fitted a Michaelis-Menten equation to the $\mathrm{Cd}$ uptake. A similar behavior was also observed in the uptake of $\mathrm{Cd}$ by sunflower plants, also in soil [36], indicating that the uptake pattern is strongly dependent on the type of growing media.

For $\mathrm{Cr}, \mathrm{Pb}$ (two non-essential elements for plants), and $\mathrm{Zn}$ (a plant micronutrient), the most adequate model to describe the accumulation in the plant was the linear model, for all the experimental treatments (S, SC, and SE). As was observed for $\mathrm{Cd}$ and $\mathrm{Ni}$, the presence of the two amendments did not change the uptake behavior, as some differences were found but were not statistically significant. For $\mathrm{Cr}, \mathrm{Pb}$, and $\mathrm{Zn}$ the levels accumulated in the edible part of the contaminated plants increase proportionally to the levels present in the soil. This shows that up to the maximum mass fractions studied for these elements (800 mg kg ${ }^{-1}$ for $\mathrm{Cr}, 1200 \mathrm{mg} \mathrm{kg}^{-1}$ for $\mathrm{Pb}$ and for $\mathrm{Zn}$ ) there is still no tendency for the uptake to stabilize in a plateau. The much higher slope for $\mathrm{Zn}$ reflects the much greater $\mathrm{Zn}$ uptake by lettuce compared to the uptake of the non-essential elements $\mathrm{Pb}$ and $\mathrm{Cr}$.

\subsection{PTE Accumulation}

For all treatments (S, SC, and SE) there were significant increases in Cd content in lettuce leaves for all of the applied Cd levels in soil. A maximum of $93 \pm 1 \mathrm{mg} \mathrm{Cd} \mathrm{kg}^{-1} \mathrm{DW}$ was detected in plants growing in non-amended soil (S) contaminated with $12 \mathrm{mg} \mathrm{Cd} \mathrm{kg}^{-1}$. With the addition of organic correctives, there was a marked decrease in the accumulation of this PTE in plants, both with SC ( $80 \pm 3 \mathrm{mg} \mathrm{Cd} \mathrm{kg}^{-1} \mathrm{DW}$, a $14.7 \%$ decrease) and with SE (72 $\pm 1 \mathrm{mg} \mathrm{Cd} \mathrm{kg}^{-1} \mathrm{DW}$, a $23.0 \%$ decrease). This difference between treatments was only significant from the mass fraction of $3 \mathrm{mg} \mathrm{Cd} \mathrm{kg}^{-1}$ in the soil, and upwards. For all mass fractions, the addition of SE always caused a decrease in Cd uptake by lettuce plants. Under all conditions, no toxicity symptoms were detected in the plants.

Adding these amendments probably lead to Cd sorption to the added organic compounds, which explain the reduced availability to the lettuce plants. Another effect that can reduce the uptake of PTE by plants is the increase in $\mathrm{pH}$ due to the added amendments [22]. In the present work, although there was a slight increase in soil pH (S: $6.9 \pm 0.1$; SC: 7.2 \pm 0.1 ; SE: $7.1 \pm 0.1$ ), it remained in the neutral zone and was not enough to affect the PTE uptake. These effects have been previously described in different studies regarding the reduced uptake of different PTE by plants under different soil amendments [37-39]. However, the effect is highly dependent upon the plant and the type and amount of amendment, as an increase in Cd uptake with the addition of organic amendments has also been reported $[40,41]$.

To the best of our knowledge there have been no studies carried out with cork residues as soil amendments to reduce PTE uptake, which relate their capacity for adsorption of PTE in the soil, and use in the remediation of contaminated soils, with only a few references to its use as an adsorbent material in gases, water, and effluents [28]. In the present study, there was only a slight decrease in Cd uptake by plants in the presence of cork powder but the effect of a conventional amendment like horse manure proved to be more efficient in this regard. It should be noticed that the cork powder used suffered no type of pre-treatment, as it has been reported that some forms of chemical treatments can lead to an increase in PTE sorption capacity [42].

Lettuce plants accumulated $\mathrm{Ni}$, and its values in lettuce ranged from $23 \pm 4 \mathrm{mg} \mathrm{kg}^{-1}$ for the lowest mass fraction of $\mathrm{Ni}$ in soil (S, $\left.37.5 \mathrm{mg} \mathrm{Ni} \mathrm{kg}^{-1}\right)$ up to $82 \pm 11 \mathrm{mg} \mathrm{kg}^{-1}$ for the highest mass fraction (SC, $37.5 \mathrm{mg} \mathrm{Ni} \mathrm{kg}^{-1}$ ). There were no significant differences in $\mathrm{Ni}$ uptake due to the presence of the organic amendments, although a slight increase tendency with both SC and SE was detected.

The uptake of $\mathrm{Cr}, \mathrm{Pb}$ and $\mathrm{Zn}$ reached a maximum of $6.1 \pm 0.2,11 \pm 1$, and $608 \pm 34 \mathrm{mg}$ $\mathrm{kg}^{-1}$, respectively, at the highest mass fraction of each PTE in soil. These results show that lettuce plants are able to tightly control the uptake of a non-essential elements like $\mathrm{Pb}$ 
and $\mathrm{Cr}$, as they are probably mostly retained at the root level with limited translocation to the shoots [43]. It has been proposed that this reduced translocation of $\mathrm{Cr}$ to the shoots is due to a conversion of $\mathrm{Cr}(\mathrm{VI})$ to $\mathrm{Cr}$ (III) and the binding of this latest form, to root cell walls [10]. Visual symptoms of toxicity were only detected for the highest $\mathrm{Cr}$ and $\mathrm{Pb}$ mass fraction in the soil of $800 \mathrm{mg} \mathrm{kg}^{-1}$ and $1200 \mathrm{mg} \mathrm{kg}^{-1}$, respectively. The accumulated $\mathrm{Pb}$ values were very similar to those accumulated by the lettuce plants contaminated with $\mathrm{Cr}$, and much lower than those accumulated by the plant exposed to $\mathrm{Cd}$, although the mass fractions applied in the soils are very different. In the case of $\mathrm{Zn}$, the accumulated values are of a much higher order of magnitude, indicating a very high mass fraction of this element in the plant, resulting from its essential micronutrient character. Despite the fact that $\mathrm{Zn}$ is an essential micronutrient, visual symptoms were detected for $\mathrm{Zn}$ content in soil as low as $300 \mathrm{mg} \mathrm{kg}^{-1}$, although the effects were much more pronounced at $1200 \mathrm{mg} \mathrm{kg}^{-1}$. At this highest $\mathrm{Zn}$ levels in the soils, $\mathrm{Zn}$ contents in plants reached a maximum of $608 \pm 34 \mathrm{mg} \mathrm{kg}^{-1} \mathrm{DW}$ which is well above the usual $\mathrm{Zn}$ mass fraction usually considered as toxic for plants (300 $\mathrm{mg} \mathrm{kg}^{-1} \mathrm{DW}$ ) [44], as this essential element is known to accumulate in lettuce leaves [45].

The presence of the two organic amendments did not affect the uptake of $\mathrm{Cr}$ or $\mathrm{Pb}$, but seemed to alleviate some of the toxic effects of excess $\mathrm{Zn}$, as the difference in biomass (see below) only decreased significantly for SC and SE plants under $1200 \mathrm{mg} \mathrm{Zn} \mathrm{kg}{ }^{-1}$. However, there were no differences in Zn uptake between control and amended soils for all the studied mass fractions.

Other studies on the application of different organic correctives to soils contaminated with $\mathrm{Cr}$ have also reported no significant effects in $\mathrm{Cr}$ uptake by different plants [46], while it has also been reported that soil amendments like manure and vermiculite can reduce Cr toxicity to crops [47,48]. McBride, et al. [49] also observed that a compost based on bovine manure had no significant effect in reducing the transfer of $\mathrm{Pb}$ from the soil to lettuce plants. The authors attribute these results to the low solubility and availability of $\mathrm{Pb}$ in the soil, due to the inherent high organic matter content and the fact that the soil $\mathrm{pH}$ is almost neutral. However other studies confirmed the reduced availability of $\mathrm{Pb}$ to plants, due to the application of different amendments [50,51]. Several studies on the effect of soil amendments on $\mathrm{Zn}$ absorption by plants have mentioned different effects, as these are probably highly dependent on the type of soil and of the amendment, plant species and $\mathrm{Zn}$ mass fraction [24,50].

\subsection{Evaluation of Vegetable Contamination}

Lettuce is a highly consumed vegetable and so it is important to evaluate the uptake of PTE in relation to its maximum acceptable levels. European Union regulations limit the amount of $\mathrm{Cd}$ in leaf vegetables to $0.2 \mathrm{mg} \mathrm{kg}^{-1} \mathrm{FW}$ [52]. In all the $\mathrm{Cd}$ mass fractions in the soil (between 1.5 and $12 \mathrm{mg} \mathrm{kg}^{-1}$ ) and all the modalities under study (S, SC, and $\mathrm{SE})$, the Cd levels in lettuce leaves exceeded that reference value. Considering the water content of lettuce (an average of $96.2 \%$ ), the values of $\mathrm{Cd}$ mass fraction in lettuce leaves ranged from a lower value of $0.73 \mathrm{mg} \mathrm{kg}^{-1} \mathrm{FW}\left(\mathrm{S},[\mathrm{Cd}]_{\text {soil }}=1.5 \mathrm{mg} \mathrm{kg}^{-1}\right)$ to the highest of $3.63 \mathrm{mg} \mathrm{kg}^{-1} \mathrm{FW}\left(\mathrm{S},[\mathrm{Cd}]_{\text {soil }}=12 \mathrm{mg} \mathrm{kg}^{-1}\right)$. Thus, even at the lowest $\mathrm{Cd}$ mass fraction in the soil of $1.5 \mathrm{mg} \mathrm{kg}^{-1}$ lettuce plants in all modalities exceeded the legislated values, while at the same time the plants showed no toxicity effects, which can present a food safety hazard as there is no visual indication to the consumer that the plants are contaminated. Lettuce plants are reported to be accumulators of $\mathrm{Cd}$ and they can easily exceed the defined maximum allowable limits when grown in soils with relatively low Cd contents [53].

Normal Ni values in plants are reported to be around $1 \mathrm{mg} \mathrm{kg}^{-1} \mathrm{DW}[5,54]$, although Marschner and Marschner [55] refer the critical toxicity levels of $\mathrm{Ni}$ as between 10 and $50 \mathrm{mg} \mathrm{kg}^{-1} \mathrm{DW}$, depending on crop species. The values detected in the present work (a maximum of $81.74 \mathrm{mg} \mathrm{kg}^{-1} \mathrm{DW}$ ) are higher compared to the reported values in lettuce in uncontaminated soils $[56,57]$, although the plants showed no signs of toxicity. In a study of the growth of lettuce in Ni-contaminated soils, Zhao, et al. [58] reported Ni levels in 
leaves similar to the ones obtained in the present study and only detected a reduced growth for Ni mass fractions of $400 \mathrm{mg} \mathrm{kg}^{-1}$ and higher, thus confirming the high tolerance of lettuce plants to Ni. In a recent EFSA publication [59] a tolerable daily intake (TDI) of $13 \mu \mathrm{g} \mathrm{kg}^{-1}$ body weight (BW) was established. For a $70 \mathrm{~kg}$ adult this corresponds to a daily intake of $0.91 \mathrm{mg}$. Considering an average lettuce consumption of $22.5 \mathrm{~g} \mathrm{day}^{-1}$ per person (adult) [60] and the maximum value of Ni measured in lettuce leaves in the present work (81.74 $\mathrm{mg} \mathrm{kg}^{-1} \mathrm{DW}$, equivalent to $4.43 \mathrm{mg} \mathrm{kg}^{-1} \mathrm{FW}$ ), we get a daily intake of $0.10 \mathrm{mg}$ for a $70 \mathrm{~kg}$ adult, which is below the TDI. Thus, even at the highest Ni mass fraction in the soil (300 $\mathrm{mg} \mathrm{kg}^{-1}$ ) the Ni levels in lettuce are within safe levels.

Nagajyoti, et al. [5] give a range of between 0.2 and $1 \mathrm{mg} \mathrm{Cr} \mathrm{kg}^{-1} \mathrm{DW}$ as the normal values encountered in plants, and all the $\mathrm{Cr}$ mass fractions measured in the present work exceeded these values but are close to what is reported in plants growing in contaminated soils [61]. Considering the average lettuce consumption given above $\left(22.5 \mathrm{~g} \mathrm{day}^{-1}\right)$ and the TDI established by EFSA for $\mathrm{Cr}(\mathrm{III})$ of $300 \mathrm{\mu g} \mathrm{kg}^{-1} \mathrm{BW}$ [62], the uptake of $\mathrm{Cr}$ by eating lettuce even at the highest contamination level obtained in this work $\left(0.43 \mathrm{mg} \mathrm{kg}^{-1} \mathrm{FW}\right.$ corresponding to an intake of $\left.0.01 \mathrm{mg} \mathrm{day}^{-1}\right)$ is below this limit $\left(21 \mathrm{mg} \mathrm{day}^{-1}\right.$ for a $70 \mathrm{~kg}$ person). This shows that, due to the low translocation of $\mathrm{Cr}$ to upper plant parts, it is safe to ingest lettuce that grows in soils moderately contaminated with $\mathrm{Cr}$.

European Union regulations limit the amount of $\mathrm{Pb}$ in leaf vegetables to $0.3 \mathrm{mg} \mathrm{kg}^{-1}$ FW [52]. This value was exceeded for lettuce plants growing in soils containing more than $150 \mathrm{mg} \mathrm{kg}^{-1}$ for all the treatments under study (with the exception of $S$ at $300 \mathrm{mg} \mathrm{kg}^{-1}$ ). For the highest mass fraction of $\mathrm{Pb}$ in the soil a maximum of $0.94 \mathrm{mg} \mathrm{kg}^{-1} \mathrm{FW}$ of $\mathrm{Pb}$ in the leaves was detected. Thus, although $\mathrm{Pb}$ is not considered a very mobile element in plants, high mass fractions of this PTE in the soil can lead to excessive values in vegetables like lettuce.

In relation to $\mathrm{Zn}$, European Union regulations consider a tolerable upper intake level (UL) of $25 \mathrm{mg} \mathrm{Zn} \mathrm{day}^{-1}$ [63]. Considering the average consumption of lettuce referred above $\left(22.5 \mathrm{~g} \mathrm{day}^{-1}\right)$ and even at the maximum mass fraction of $Z n$ detected in the present study (70.56 mg kg ${ }^{-1} \mathrm{FW}$ ), the daily intake of Zn amounts to only $1.6 \mathrm{mg} \mathrm{Zn} \mathrm{day}^{-1}$ which is considerable below the defined UL. It should be noticed that at this mass fraction, lettuce plants already show visual toxicity symptoms which might lead to its rejection by the consumer. Thus, the consumption of lettuce growing in soils with a high $\mathrm{Zn}$ content does not pose a toxicity hazard to humans.

\subsection{Transfer Factor}

The transfer factor (TF) evaluates the transfer of PTE present in the soil to the plant, given by the proportion in the plant in relation to the levels in the growing medium. These values are shown in Figure 2 for the five PTE studied.

For $\mathrm{Cd}$ there was a clear decrease in $\mathrm{TF}_{\mathrm{Cd}}$ both with increasing $\mathrm{Cd}$ content in soil and with the presence of both amendments, with manure (SE) having a more pronounced effect than cork (SC), confirming that these amendments decrease the plant's ability to transfer the $\mathrm{Cd}$ present in the soil to the plant. The very high $\mathrm{TF}_{\mathrm{Cd}}$ are in accordance with the values accumulated in the maximum tested mass fractions, which are still below the $\mathrm{Cd}-\mathrm{C}_{\max }$. The values for $\mathrm{TF}_{\mathrm{Cd}}$ were the highest TF among the 5 PTE studied, confirming the high ability of lettuce to absorb Cd into its leaves [17]. Curiously, it was with this PTE that the amendments were most effective in reducing PTE uptake. 


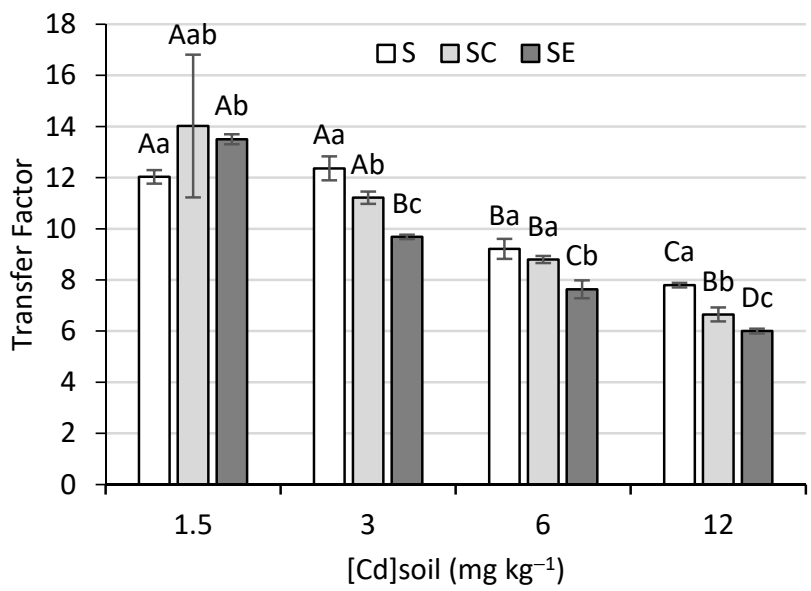

(a)

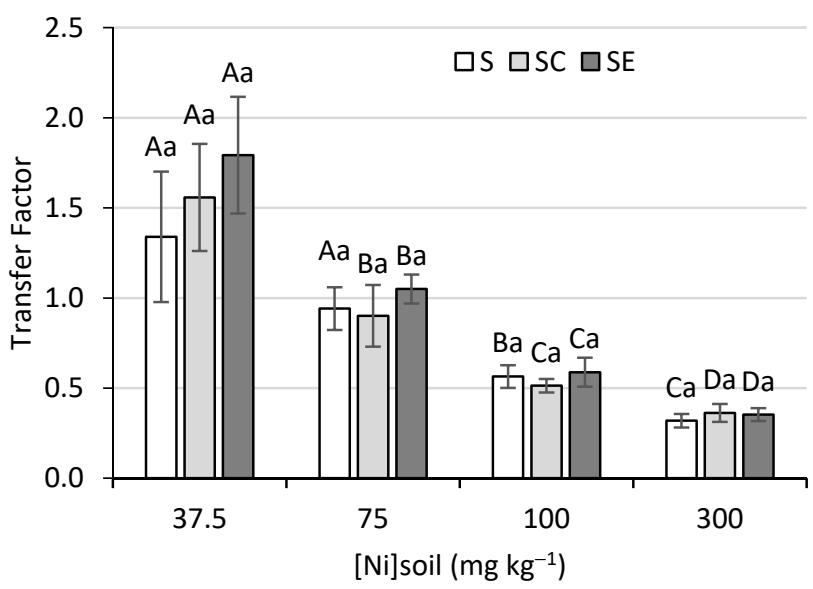

(c)

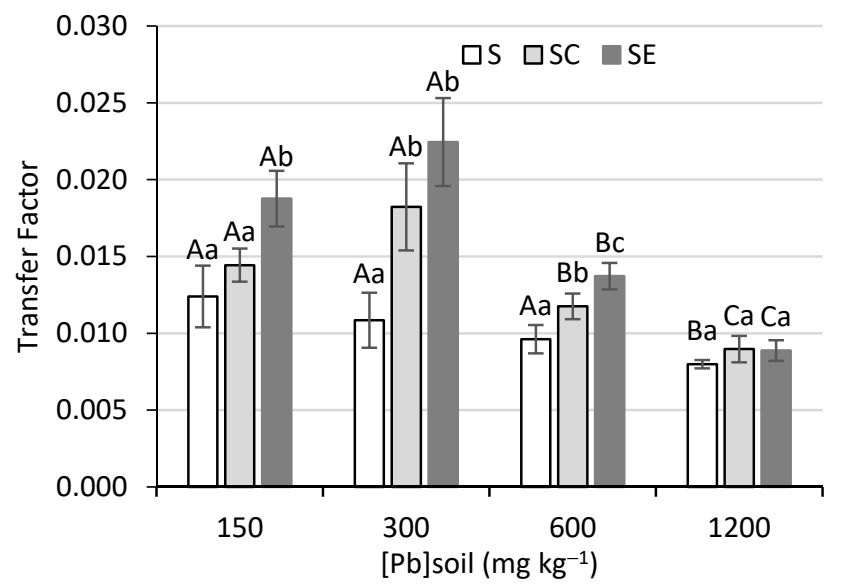

(b)

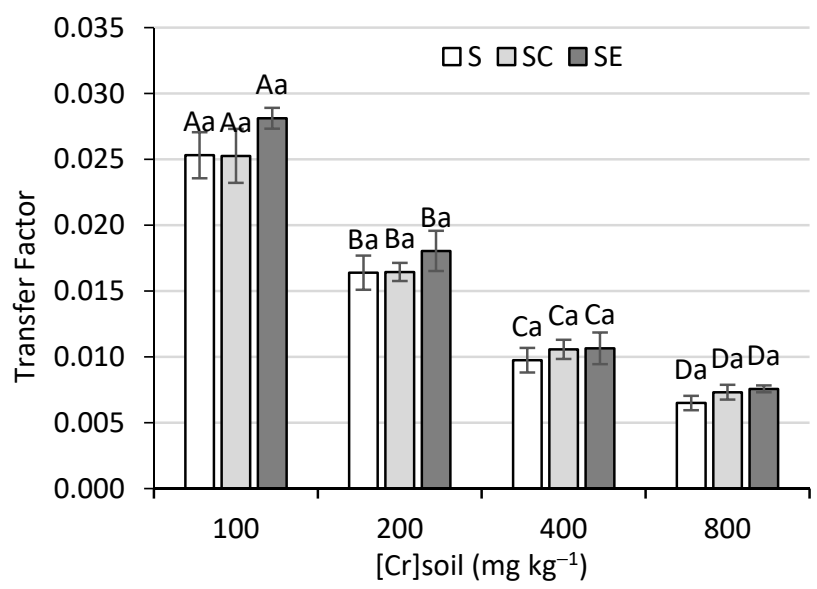

(d)

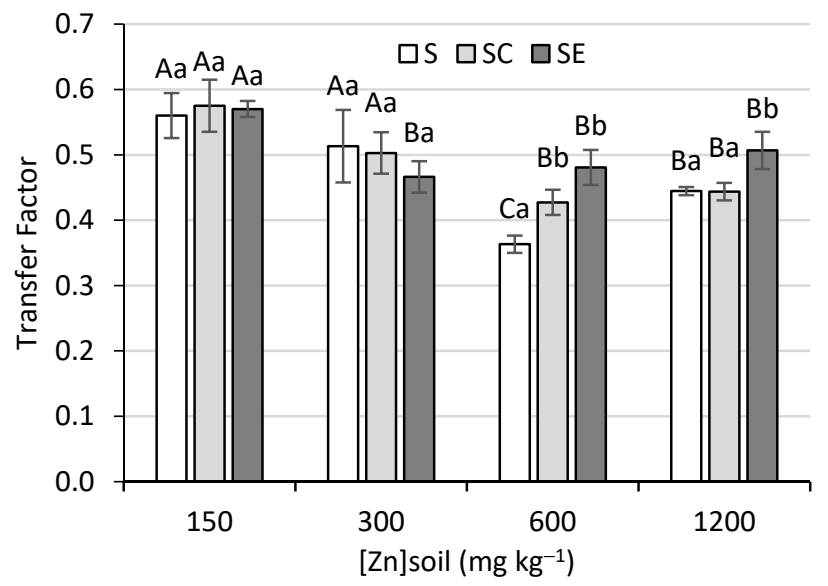

(e)

Figure 2. Transfer factor (TF) for each PTE and each treatment, non-amended soil (S), soil amended with cork powder (SC) and soil amended with horse manure (SE): (a) Cd; (b) Pb; (c) Ni; (d) $\mathrm{Cr}$; (e) $\mathrm{Zn}$.

In the case of contamination with $\mathrm{Ni}$, although a general decrease in $\mathrm{TF}_{\mathrm{Ni}}$ was observed with increasing Ni mass fraction in soil (Figure 2c) there was no significant differences with the application of both soil amendments. This decrease in $\mathrm{TF}_{\mathrm{Ni}}$ values indicates lower absorption rates, which is in accordance with the adjustment of accumulation to the hyperbolic model and the verification of a tendency towards saturation at a $\mathrm{Ni}-\mathrm{C}_{\max }$ value, mentioned above. In fact, for $\mathrm{Ni}$, the levels in the plant are closer to the $\mathrm{Ni}-\mathrm{C}_{\max }$ value, and the $\mathrm{TF}_{\mathrm{Ni}}$ reflects this situation, indicating that they are closer to saturation. Nickel uptake 
by plants has been reported to be reduced by composts [64], but with the amendments used in the present work this was not observed. A reduction of the TF of Ni in lettuce plants similar to the present work results has also been observed in a recent study with lettuce plants [58].

The values for $\mathrm{Cr}\left(\mathrm{TF}_{\mathrm{Cr}}\right)$ are very similar to the behavior observed for $\mathrm{Ni}$, with a general decrease with increasing $\mathrm{Cr}$ mass fraction in soil and no visible effect of the added amendments (Figure 2d). This shows that despite the increasing Cr content in soil, the plant has adequate mechanisms to control the uptake of this element. Chromium mass fractions in the plant remained low, and $\mathrm{TF}_{\mathrm{Cr}}$ values were also very low indicating a low translocation from the soil to the plant. Chromium is not a very mobile element, and it has been reported that amendments like biochar can reduce its uptake by plants [65].

The $\mathrm{TF}$ for $\mathrm{Pb}\left(\mathrm{TF}_{\mathrm{Pb}}\right)$ exhibits a different behavior from the other PTE (Figure $2 \mathrm{~b}$ ). Although there is also a general decrease with increasing $\mathrm{Pb}$ in soil, there is a significant increase with the presence of amendments (more pronounced for horse manure, SE), except at the highest mass fraction of $1200 \mathrm{mg} \mathrm{kg}^{-1}$. In absolute terms, the $\mathrm{TF}_{\mathrm{Pb}}$ values, together with those for $\mathrm{Cr}$, are the lowest of the five PTE studied, showing the low mobility of these elements in plants, which has been previously reported [66]. Despite the low $\mathrm{TF}_{\mathrm{Pb}}$ values, the levels of $\mathrm{Pb}$ in the plant present a contamination hazard as described above.

In relation to $\mathrm{Zn}$, there were no significant differences in $\mathrm{TF}_{\mathrm{Zn}}$ for the two lowest soil $\mathrm{Zn}$ mass fractions (150 and $300 \mathrm{mg} \mathrm{kg}^{-1}$ ), but for the two highest mass fractions, there was an increase with the applied amendments, more pronounced for horse manure (Figure 2e). Thus, for the highest $\mathrm{Zn}$ mass fractions in soil, the presence of the amendments actually increased the uptake of $\mathrm{Zn}$ by lettuce plants in relation to the soil content.

Generally, the order of TF values was $\mathrm{Cd}>\mathrm{Ni}>\mathrm{Zn}>\mathrm{Cr} \approx \mathrm{Pb}$. Khan, et al. [67] also measured the TF values of several PTE and while they present the highest value for $\mathrm{Cd}$, they also indicated a TF for $\mathrm{Pb}$ higher than for $\mathrm{Zn}$ or $\mathrm{Ni}$ (for lettuce plants). These differences could be due to PTE mass fraction in the soil (for example, in the present study we observed an almost five-fold difference in $\mathrm{TF}_{\mathrm{Ni}}$ between the highest and the lowest $\mathrm{Ni}$ mass fractions in soil) and also to soil characteristics and contamination source. In a different study [68] TF in the order of $\mathrm{Cd}>\mathrm{Zn}>\mathrm{Pb}$ was also reported, with very low values for $\mathrm{Pb}$ similar to the ones of the present work (although at lower PTE mass fractions in the soil). Similar results were obtained in another study with lettuce with $\mathrm{Cr}$ having the lowest TF [69].

\subsection{Tolerance Index}

The Tolerance Index (TI) provides important information about phytotoxicity because it is based on plant biomass (fresh mass) and reflects the negative effect of accumulation on plant development. Thus, a decrease in TI indicates less biomass (in relation to the control) and therefore greater toxicity of each PTE. In Figure 3, the TI for all the PTE studied are presented.

In plants exposed to $\mathrm{Cd}$, a lower TI only for control plants growing in the two highest Cd mass fractions ( 6 and $12 \mathrm{mg} \mathrm{kg}^{-1}$ ) was obtained, showing that both soil amendments attenuated, albeit slightly, the toxic effects for $\mathrm{Cd}$.

For the Ni assay, no differences were observed in the $\mathrm{TI}_{\mathrm{Ni}}$ and this reflects the tolerance of lettuce to Ni toxicity, as no visual indicators of toxicity were detected. As the Ni effects were not noticeable (up to the mass fractions studied) there was also no differences with the application of both organic amendments. 


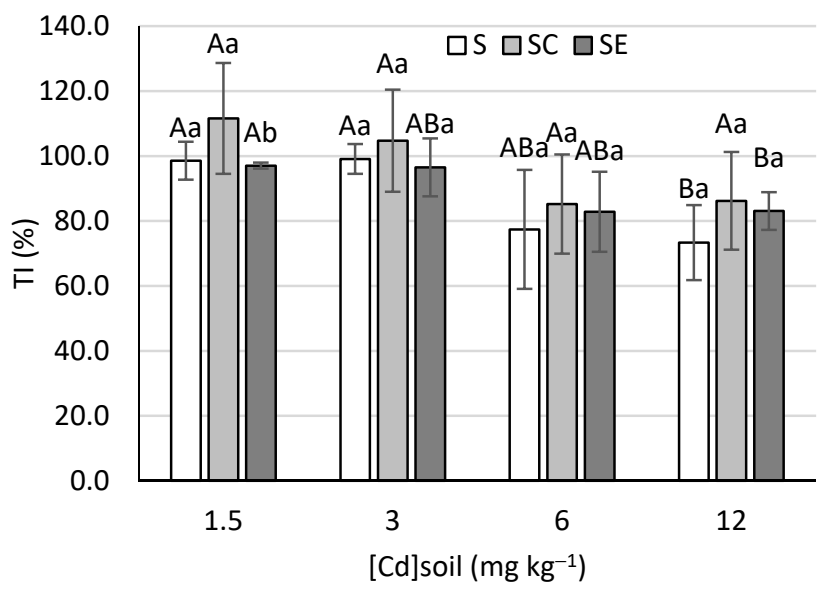

(a)

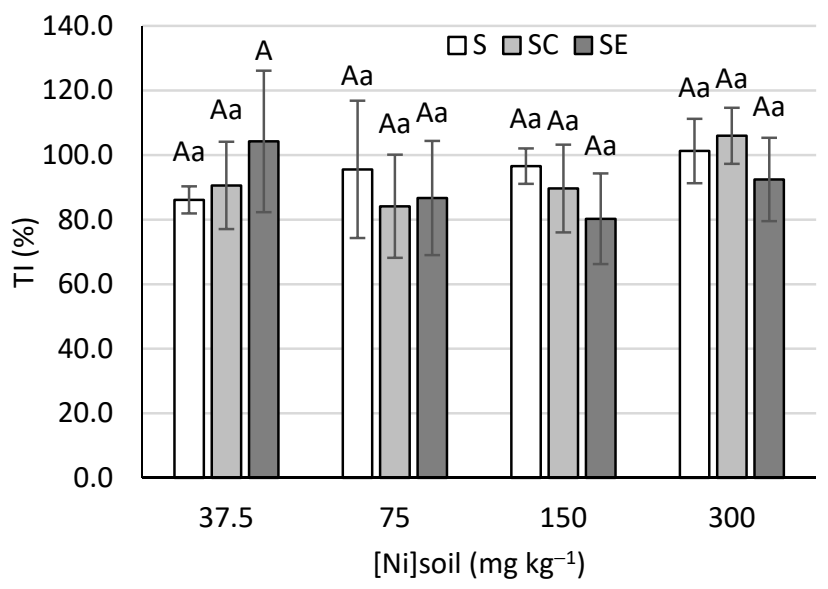

(c)

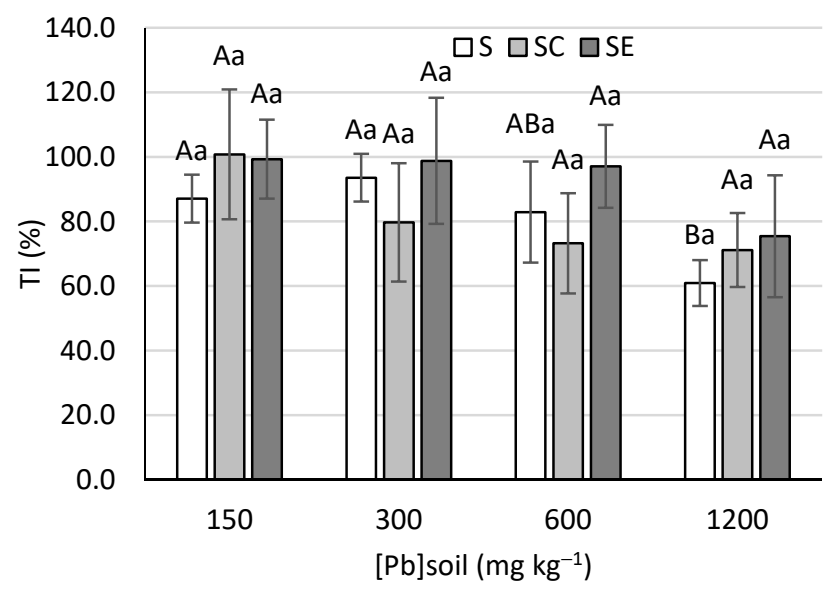

(b)

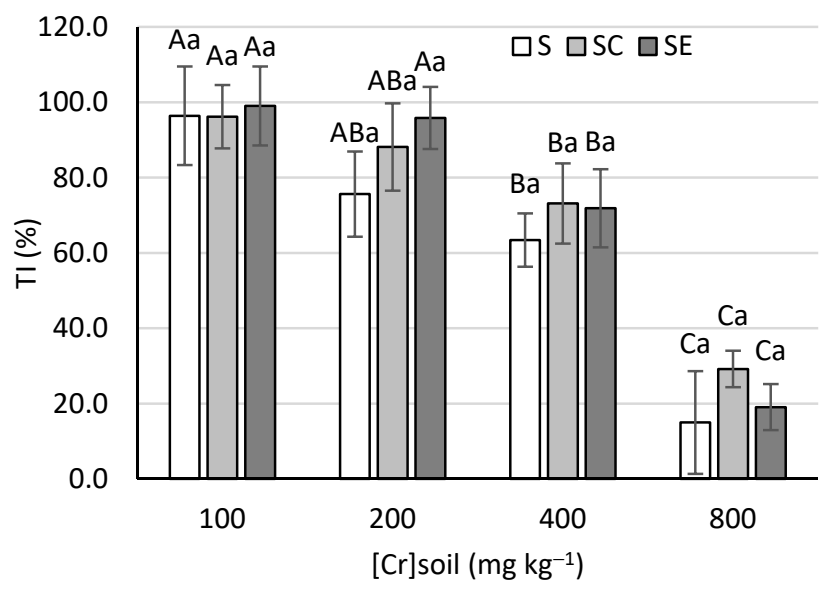

(d)

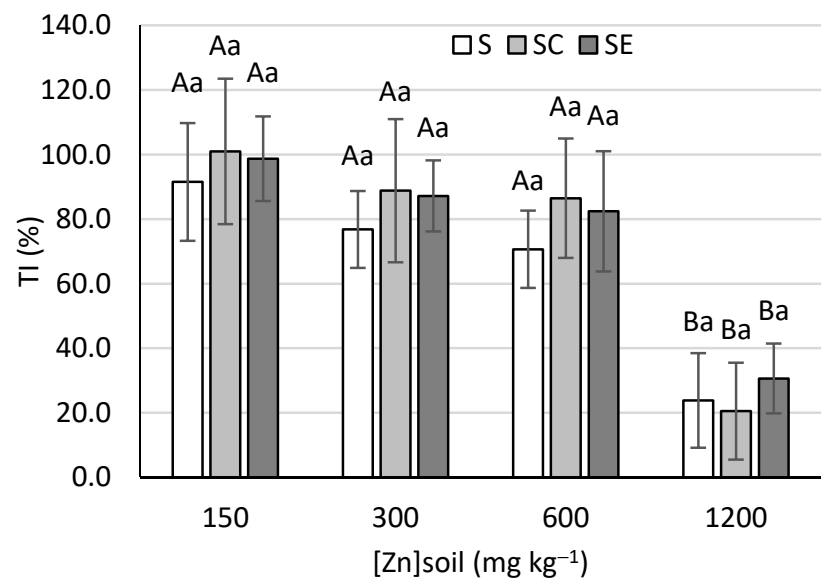

(e)

Figure 3. Tolerance Index (TI) for each PTE and each treatment, non-amended soil (S), soil amended with cork powder (SC) and soil amended with horse manure (SE): (a) $\mathrm{Cd}$; (b) $\mathrm{Pb}$; (c) $\mathrm{Ni}$; (d) $\mathrm{Cr}$; (e) $\mathrm{Zn}$.

In soils contaminated with $\mathrm{Pb}$, the $\mathrm{TI}_{\mathrm{Pb}}$ was reduced in non-amended soils for 600 and $1200 \mathrm{mg} \mathrm{kg}^{-1}$ mass fractions. The $\mathrm{TI}_{\mathrm{Pb}}$ with amendments (SC and SE) improved slightly, showing that, although the $\mathrm{Pb}$ levels in lettuce are not significantly reduced, growing lettuce with these amendments (especially for manure) can attenuate the effects of $\mathrm{Pb}$ toxicity.

The effects for $\mathrm{Cr}$ and $\mathrm{Zn}$ were similar, with a general decrease in TI for the two highest mass fractions, much more noticeable at the higher mass fraction. Although in both cases 
there was a slight increase in TI with the presence of amendments, the differences are not significantly different. For a Cr mass fraction of $800 \mathrm{mg} \mathrm{kg}^{-1}$ and a $\mathrm{Zn}$ mass fraction of $1200 \mathrm{mg} \mathrm{kg}^{-1}$ the TI value is less than $50 \%$ for contaminated plants in all modalities (S, SC, and SE), showing that this is a critical mass fraction for plant development. This behavior was observed for all treatments, with no differences for S, SC, and SE, indicating that the application of organic residues does not reduce bioavailability for the plant and does not control toxicity for plants, thus it has no effect on contamination control. Similar results have been obtained by Shu, et al. [70] that observed a strong decrease in TI with increasing concentrations of $\mathrm{Zn}$ and also $\mathrm{Pb}$.

\subsection{Cluster Analysis}

A cluster analysis was performed applying a correlation matrix to 6 normalized variables (PTE mass fraction in edible part and in soil, extractable fraction, leaf fresh weight, soil $\mathrm{pH}$, and \% of organic matter). The method followed was PAM partition into 3 classes in order to allocate different individuals according to the PTE mass fraction applied and treatment (S-non-amended soil, SC—soil with cork powder, SE-soil with horse manure). Figure 4 shows the PAM analysis for the 5 PTE applied $(\mathrm{Cd}, \mathrm{Cr}, \mathrm{Ni}, \mathrm{Pb}$, and $\mathrm{Zn}$ ). This analysis allows an evaluation of toxicity parameters, as well as the main differences among amendments applied to soil. In all presented clusters it is possible to observe a clear differentiation among modalities.

As can be seen from these figures, the main effect is caused by the element mass fraction in soil, as the highest mass fractions appear in separate groupings. This effect is much more intense than the presence of either of the added amendments, as we have in most cases all three treatments (S, SC, and SE) present in the identified groups. For $\mathrm{Cd}, \mathrm{Ni}$, $\mathrm{Cr}$, and $\mathrm{Pb}$ (Figure $4 \mathrm{a}-\mathrm{d}$ ) there are three clearly defined groups corresponding to the control and the lowest PTE mass fraction, another group for the intermediate ones, and another one for the highest mass fractions. For $\mathrm{Zn}$, the most clearly defined group is for the highest $\mathrm{Zn}$ mass fraction of $1200 \mathrm{mg} \mathrm{kg}^{-1}$, where the effects were more pronounced. For Pb and $\mathrm{Zn}$, two classes presented overlap conditions, namely the ones including control and lower mass fractions individuals and medium mass fractions, while in $\mathrm{Cd}$ the slight overlap was between the medium and the highest mass fractions, showing the more toxic effect of $\mathrm{Cd}$.

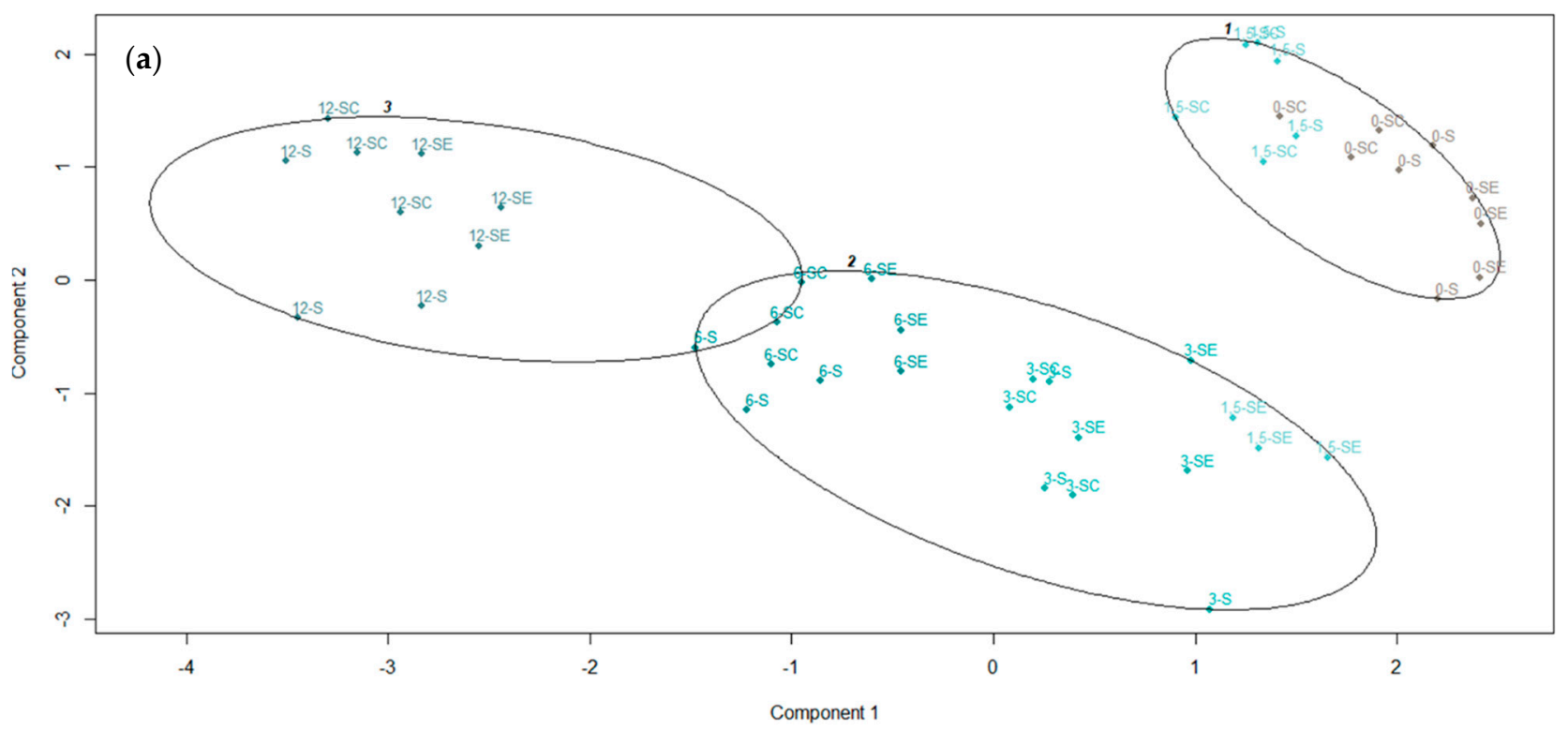

Figure 4. Cont. 

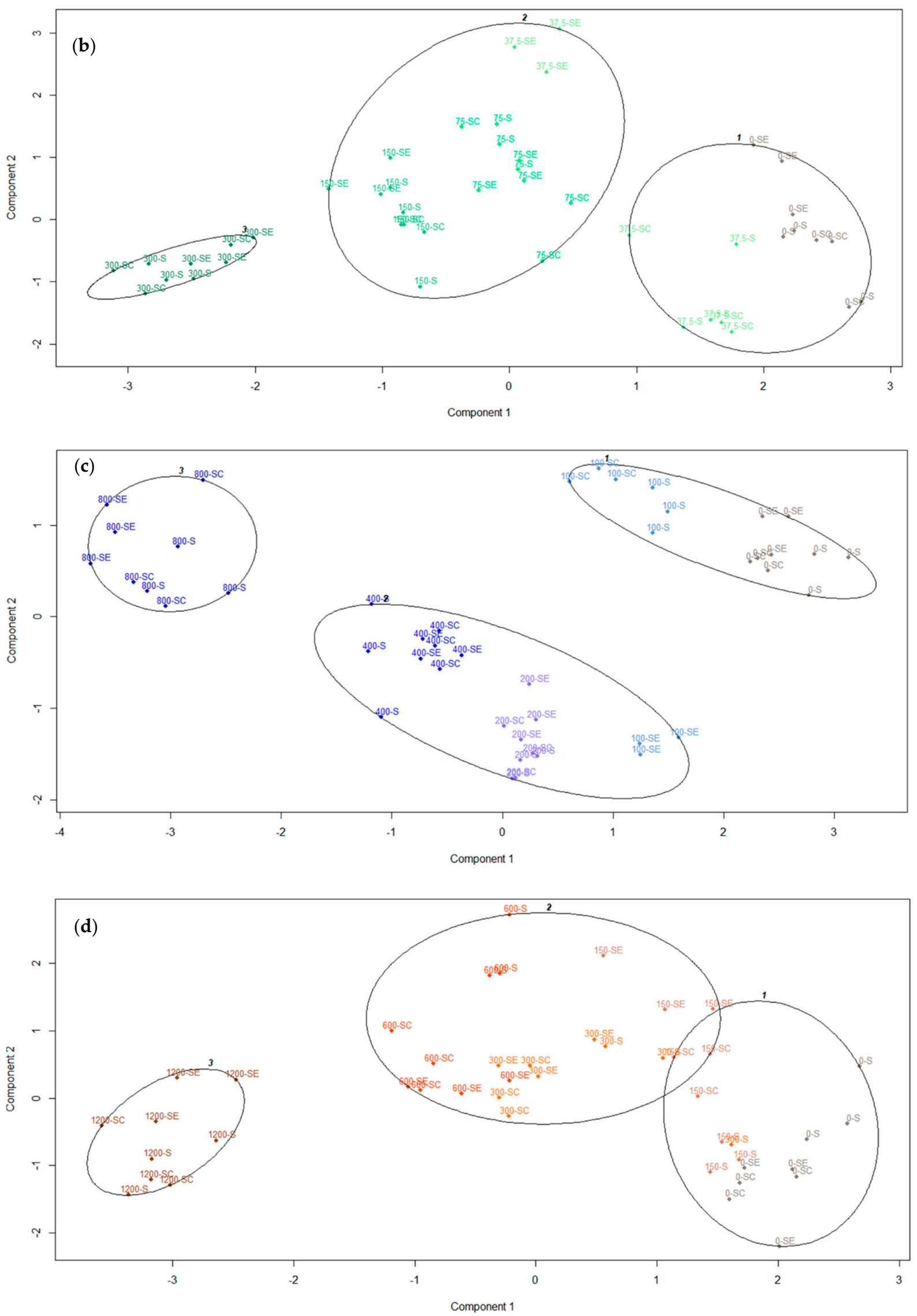

Figure 4. Cont. 


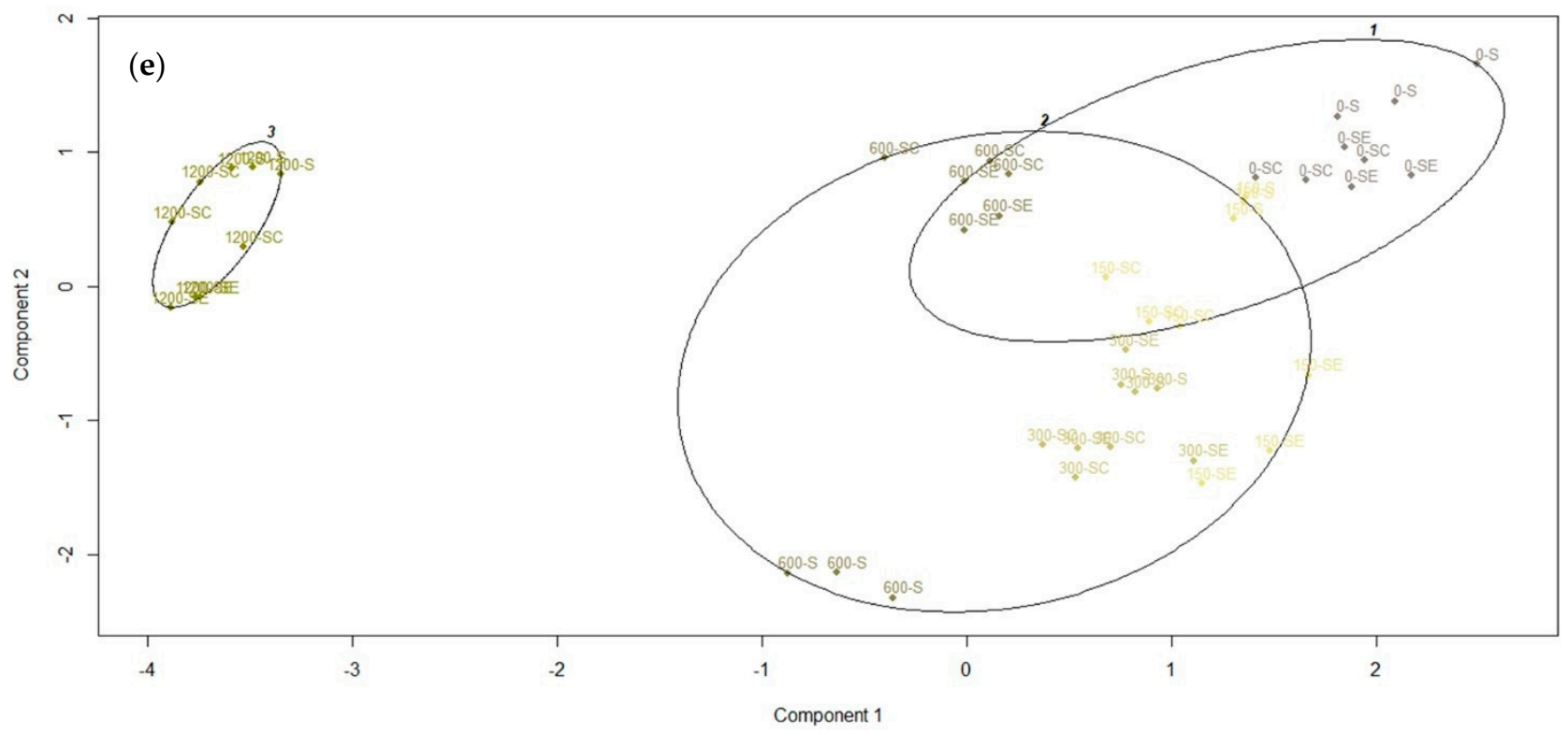

Figure 4. Clusters obtained using the PAM method for the effects of the 5 PTE under study: (a) Cd; (b) Pb; (c) Ni; (d) Cr; (e) $\mathrm{Zn}$.

\subsection{Pratical Implications of This Work}

The present work confirmed that different PTE can be absorbed by edible plants and can reach concentrations that are harmful to human beings, especially in relation to $\mathrm{Cd}$ and $\mathrm{Pb}$. These two elements have very different mobilities in plants, but can both reach high contents. Although the amount of $\mathrm{Cr}$ and Ni taken up by the plants is not very high, there should be more clear legislation regarding the safe levels of these elements in edible vegetables. The application of amendments can lead to a reduction in PTE uptake by plants, but its efficiency is highly dependent on the type, characteristics, and mass fraction of the amendment in the soil. The cork subproduct was not very efficient in reducing PTE uptake by plants (except for $\mathrm{Cd}$ ) so the possibility of making some sort of chemical treatment should be explored in the future.

\section{Conclusions}

Of the non-essential elements studied $(\mathrm{Cd}, \mathrm{Cr}$, and $\mathrm{Pb}), \mathrm{Cd}$ is by far the most mobile in the plant with higher contents detected compared to $\mathrm{Pb}$ and $\mathrm{Cr}$, even if its mass fraction in the soils is much lower. This resulted in Cd contents in lettuce that were higher than the maximum allowable limits. The legislated limits were also exceeded with $\mathrm{Pb}$ (but only for soil contents higher than $150 \mathrm{mg} \mathrm{kg}^{-1}$ ). The values of $\mathrm{Cr}$, $\mathrm{Ni}$ and $\mathrm{Zn}$ accumulated in lettuce were considered acceptable at all mass fractions studied.

The addition of organic amendments only was effective on reducing the uptake of $\mathrm{Cd}$ by lettuce plants but has no effect on the uptake of the other PTE. For $\mathrm{Cr}, \mathrm{Ni}, \mathrm{Zn}$, and $\mathrm{Pb}$, the application of the amendments did not cause a significant reduction in uptake and accumulation in plants. When the results between both organic residues are compared, cork is shown to be less efficient than horse manure in controlling the bioavailability of PTE for plants.

It can be concluded that the application of these organic correctives (cork and horse manure) is only promising for the remediation of soils contaminated with cadmium, given that only for this element there was a decrease in accumulation in the plant. Under the conditions of the present work, the presence of both organic correctives had no influence on the $\mathrm{Cr}, \mathrm{Pb}, \mathrm{Ni}$, and $\mathrm{Zn}$ content accumulated in the plant.

The application of mathematical models to explain the behavior of each PTE allows us, within certain limits, to predict and characterize the accumulation in the plant under the studied conditions. The application of higher amounts of these organic correctives should 
be considered, so that the accumulation of $\mathrm{Cd}$ in the plant is reduced to values that do not constitute a risk to the food chain. This is particularly important if we take into account that toxicity symptoms are not visible even for significant amounts of $\mathrm{Cd}$ in the plant.

Author Contributions: Conceptualization, methodology and supervision M.P.M. and L.L.M.; investigation, I.M. and I.L.; writing-original draft preparation, L.L.M. and I.L.; writing-review and editing, M.P.M. All authors have read and agreed to the published version of the manuscript.

Funding: This research was funded by FCT_Fundação para a Ciência e Tecnologia (PhD grant SFRH/BD/89557/2012 and grant PTDC/AGR-AAM/102821/2008) and FCT-funded research unit LEAF (UID/AGR/04129/2020).

Institutional Review Board Statement: Not applicable.

Informed Consent Statement: Not applicable.

Data Availability Statement: Not applicable.

Acknowledgments: Horse manure and cork powder were kindly given by the Portuguese Equestrian Society (Sociedade Hípica Portuguesa) and by Robcork, respectively.

Conflicts of Interest: The authors declare no conflict of interest.

\section{References}

1. Alloway, B.J. Heavy Metals in Soils, 3rd ed.; Springer: Berlin/Heidelberg, Germany, 2013; Volume 22.

2. Tóth, G.; Hermann, T.; Szatmári, G.; Pásztor, L. Maps of heavy metals in the soils of the European Union and proposed priority areas for detailed assessment. Sci. Total Environ. 2016, 565, 1054-1062. [CrossRef]

3. Gall, J.E.; Boyd, R.S.; Rajakaruna, N. Transfer of heavy metals through terrestrial food webs: A review. Environ. Monit. Assess. 2015, 187, 1-21. [CrossRef] [PubMed]

4. Clemens, S.; Ma, J.F. Toxic Heavy Metal and Metalloid Accumulation in Crop Plants and Foods. Annu. Rev. Plant Biol. 2016, 67, 489-512. [CrossRef] [PubMed]

5. Nagajyoti, P.C.; Lee, K.D.; Sreekanth, T.V.M. Heavy metals, occurrence and toxicity for plants: A review. Environ. Chem. Lett. 2010, 8, 199-216. [CrossRef]

6. Ertani, A.; Mietto, A.; Borin, M.; Nardi, S. Chromium in Agricultural Soils and Crops: A Review. Water Air Soil Pollut. 2017, 228, 190. [CrossRef]

7. Agência Portuguesa do Ambiente Solos Contaminados-Guia Técnico. 2019. Available online: https://sniambgeoviewer. apambiente.pt/GeoDocs / geoportaldocs / AtQualSolos/Guia_Tecnico_Valores\%20de\%20Referencia_2019_01.pdf (accessed on 8 March 2021).

8. Canadian Ministry of the Environment. Soil, Ground Water and Sediment Standards for Use under Part XV.1 of the Environmental Protection Act. in 2011; Canadian Ministry of the Environment: Toronto, ON, Canada, 2011.

9. Shanker, A.K.; Cervantes, C.; Loza-Tavera, H.; Avudainayagam, S. Chromium toxicity in plants. Environ. Int. 2005, 31, 739-753. [CrossRef] [PubMed]

10. Shahid, M.; Shamshad, S.; Rafiq, M.; Khalid, S.; Bibi, I.; Niazi, N.K.; Dumat, C.; Rashid, M.I. Chromium speciation, bioavailability, uptake, toxicity and detoxification in soil-plant system: A review. Chemosphere 2017, 178, 513-533. [CrossRef] [PubMed]

11. Chen, C.; Huang, D.; Liu, J. Functions and Toxicity of Nickel in Plants: Recent Advances and Future Prospects. Clean Soil Air Water 2009, 37, 304-313. [CrossRef]

12. Yusuf, M.; Fariduddin, Q.; Hayat, S.; Ahmad, A. Nickel: An Overview of Uptake, Essentiality and Toxicity in Plants. Bull. Environ. Contam. Toxicol. 2011, 86, 1-17. [CrossRef]

13. De Temmerman, L.; Vanongeval, L.; Boon, W.; Hoenig, M.; Geypens, M. Heavy Metal Content of Arable Soils in Northern Belgium. Water Air Soil Pollut. 2003, 148, 61-76. [CrossRef]

14. Broadley, M.R.; White, P.J.; Hammond, J.P.; Zelko, I.; Lux, A. Zinc in plants. New Phytol. 2007, 173, 677-702. [CrossRef] [PubMed]

15. Alloway, B. Zinc in Soils and Crop Nutrition, 2nd ed.; IZA: Brussels, Belgium; IFA: Paris, France, 2008.

16. Sofo, A.; Moreira, I.; Gattullo, C.E.; Martins, L.L.; Mourato, M. Antioxidant responses of edible and model plant species subjected to subtoxic zinc concentrations. J. Trace Elem. Med. Biol. 2018, 49, 261-268. [CrossRef] [PubMed]

17. Degryse, F.; Smolders, E.; Merckx, R. Labile Cd Complexes Increase Cd Availability to Plants. Environ. Sci. Technol. 2006, 40, 830-836. [CrossRef] [PubMed]

18. Rizwan, M.; Ali, S.; Adrees, M.; Ibrahim, M.; Tsang, D.C.; Zia-Ur-Rehman, M.; Zahir, Z.A.; Rinklebe, J.; Tack, F.M.; Ok, Y.S. A critical review on effects, tolerance mechanisms and management of cadmium in vegetables. Chemosphere 2017, 182, 90-105. [CrossRef]

19. Yan, K.; Dong, Z.; Wijayawardena, M.; Liu, Y.; Naidu, R.; Semple, K. Measurement of soil lead bioavailability and influence of soil types and properties: A review. Chemosphere 2017, 184, 27-42. [CrossRef] [PubMed] 
20. Shahid, M.; Pinelli, E.; Dumat, C. Review of Pb availability and toxicity to plants in relation with metal speciation; role of synthetic and natural organic ligands. J. Hazard. Mater. 2012, 219-220, 1-12. [CrossRef] [PubMed]

21. Datko-Williams, L.; Wilkie, A.; Richmond-Bryant, J. Analysis of U.S. soil lead (Pb) studies from 1970 to 2012. Sci. Total Environ. 2014, 468-469, 854-863. [CrossRef]

22. Khan, M.A.; Khan, S.; Khan, A.; Alam, M. Soil contamination with cadmium, consequences and remediation using organic amendments. Sci. Total Environ. 2017, 601-602, 1591-1605. [CrossRef] [PubMed]

23. Gautam, M.; Agrawal, M. Effects of red mud addition in soil fertilized with cowdung manure on growth performance and metal accumulations in Brassica juncea cultivars Kranti and Pusa Bold. Commun. Soil Sci. Plant Anal. 2019, 50, 1214-1231. [CrossRef]

24. Wolf, M.; Baretta, D.; Becegato, V.A.; Almeida, V.D.C.; Paulino, A.T. Copper/Zinc Bioaccumulation and the Effect of Phytotoxicity on the Growth of Lettuce (Lactuca sativa L.) in Non-contaminated, Metal-Contaminated and Swine Manure-Enriched Soils. Water Air Soil Pollut. 2017, 228, 152. [CrossRef]

25. Alvarenga, P.; Rodrigues, D.; Mourinha, C.; Palma, P.; De Varennes, A.; Cruz, N.; Tarelho, L.A.; Rodrigues, S. Use of wastes from the pulp and paper industry for the remediation of soils degraded by mining activities: Chemical, biochemical and ecotoxicological effects. Sci. Total Environ. 2019, 686, 1152-1163. [CrossRef] [PubMed]

26. Sigua, G.C.; Novak, J.M.; Watts, D.W.; Ippolito, J.A.; Ducey, T.F.; Johnson, M.G.; Spokas, K.A. Phytostabilization of Zn and Cd in Mine Soil Using Corn in Combination with Biochars and Manure-Based Compost. Environments 2019, 6, 69. [CrossRef]

27. Guiwei, Q.; De Varennes, A.; Martins, L.L.; Mourato, M.; Cardoso, A.; Mota, A.M.; Pinto, A.; Gonçalves, M. Improvement in soil and sorghum health following the application of polyacrylate polymers to a Cd-contaminated soil. J. Hazard. Mater. 2010, 173, 570-575. [CrossRef] [PubMed]

28. Pintor, A.M.; Ferreira, C.I.; Pereira, J.C.; Correia, P.; Silva, S.P.; Vilar, V.J.; Botelho, C.M.; Boaventura, R.A. Use of cork powder and granules for the adsorption of pollutants: A review. Water Res. 2012, 46, 3152-3166. [CrossRef] [PubMed]

29. Peijnenburg, W.; Baerselman, R.; De Groot, A.; Jager, T.; Leenders, D.; Posthuma, L.; Van Veen, R. Quantification of Metal Bioavailability for Lettuce (Lactuca sativa L.) in Field Soils. Arch. Environ. Contam. Toxicol. 2000, 39, 420-430. [CrossRef]

30. MAOTDR, Ministério do Ambiente, do Ordenamento do Território e do Desenvolvimento Regional. Decreto-Lei No. $276 / 2009$. 2009. Available online: https:/ / data.dre.pt/eli/dec-lei/276/2009/10/02/p/dre/pt/html (accessed on 8 March 2021).

31. Ribeiro, D.M.; Scanlon, T.; Kilminster, T.; Martins, C.F.; Greeff, J.; Milton, J.; Oldham, C.; Freire, J.P.B.; Mourato, M.P.; De Almeida, A.M. Mineral profiling of muscle and hepatic tissues of Australian Merino, Damara and Dorper lambs: Effect of weight loss. J. Anim. Physiol. Anim. Nutr. 2020, 104, 823-830. [CrossRef] [PubMed]

32. Rossato, L.; Macfarlane, J.; Whittaker, M.; Pudmenzky, A.; Doley, D.; Schmidt, S.; Monteiro, M. Metal-binding particles alleviate lead and zinc toxicity during seed germination of metallophyte grass Astrebla lappacea. J. Hazard. Mater. 2011, 190, 772-779. [CrossRef]

33. Batra, D.A. Analysis and Approach: K-Means and K-Medoids Data Mining Algorithms. In Proceedings of the 5th IEEE International Conference on Advanced Computing \& Communication Technologies, Panipat, India, 5 November 2011; Choudhary, R.K., Verma, M., Saini, S., Eds.; pp. 274-279.

34. Stritsis, C.; Claassen, N. Cadmium uptake kinetics and plants factors of shoot Cd concentration. Plant Soil 2013, 367, 591-603. [CrossRef]

35. Chen, W.; Li, L.; Chang, A.C.; Wu, L.; Kwon, S.-I.; Bottoms, R. Modeling uptake kinetics of cadmium by field-grown lettuce. Environ. Pollut. 2008, 152, 147-152. [CrossRef]

36. Rivelli, A.R.; Puschenreiter, M.; De Maria, S. Assessment of cadmium uptake and nutrient content in sunflower plants grown under Cd stress. Plant Soil Environ. 2014, 60, 80-86. [CrossRef]

37. Liu, L.; Chen, H.; Cai, P.; Liang, W.; Huang, Q. Immobilization and phytotoxicity of Cd in contaminated soil amended with chicken manure compost. J. Hazard. Mater. 2009, 163, 563-567. [CrossRef] [PubMed]

38. Clemente, R.; Escolar, Á.; Bernal, M.P. Heavy metals fractionation and organic matter mineralisation in contaminated calcareous soil amended with organic materials. Bioresour. Technol. 2006, 97, 1894-1901. [CrossRef]

39. Lee, S.-H.; Lee, J.-S.; Jeong Choi, Y.; Kim, J.-G. In situ stabilization of cadmium-, lead-, and zinc-contaminated soil using various amendments. Chemosphere 2009, 77, 1069-1075. [CrossRef] [PubMed]

40. Bai, Y.; Gu, C.; Tao, T.; Chen, G.; Shan, Y. Straw incorporation increases solubility and uptake of cadmium by rice plants. Acta Agric. Scand. Sect. B Plant Soil Sci. 2013, 63, 193-199. [CrossRef]

41. Pinto, F.R.; Mourato, M.P.; Sales, J.R.; Fangueiro, D.; Martins, L.L. Effect of Cattle Slurry on the Growth of Spinach Plants in Cd-contaminated Soil. Commun. Soil Sci. Plant Anal. 2020, 51, 1370-1381. [CrossRef]

42. Chubar, N.; Carvalho, J.R.; Correia, M.N. Heavy metals biosorption on cork biomass: Effect of the pre-treatment. Colloids Surf. A Physicochem. Eng. Asp. 2004, 238, 51-58. [CrossRef]

43. Chandra, R.; Bharagava, R.; Yadav, S.; Mohan, D. Accumulation and distribution of toxic metals in wheat (Triticum aestivum L.) and Indian mustard (Brassica campestris L.) irrigated with distillery and tannery effluents. J. Hazard. Mater. 2009, 162, 1514-1521. [CrossRef]

44. Noulas, C.; Tziouvalekas, M.; Karyotis, T. Zinc in soils, water and food crops. J. Trace Elem. Med. Biol. 2018, 49, 252-260. [CrossRef] [PubMed]

45. Roy, M.; McDonald, L.M. Metal Uptake in Plants and Health Risk Assessments in Metal-Contaminated Smelter Soils. Land Degrad. Dev. 2015, 26, 785-792. [CrossRef] 
46. Karak, T.; Paul, R.K.; Sonar, I.; Sanyal, S.; Ahmed, K.Z.; Boruah, R.K.; Das, D.K.; Dutta, A.K. Chromium in soil and tea (Camellia sinensis L.) infusion: Does soil amendment with municipal solid waste compost make sense? Food Res. Int. 2014, 64, 114-124. [CrossRef]

47. Singh, G.; Brar, M.S.; Malhi, S.S. Decontamination of Chromium by Farm Yard Manure Application in Spinach Grown in Two Texturally Different Cr-Contaminated Soils. J. Plant Nutr. 2007, 30, 289-308. [CrossRef]

48. Malandrino, M.; Abollino, O.; Buoso, S.; Giacomino, A.; La Gioia, C.; Mentasti, E. Accumulation of heavy metals from contaminated soil to plants and evaluation of soil remediation by vermiculite. Chemosphere 2011, 82, 169-178. [CrossRef] [PubMed]

49. McBride, M.B.; Simon, T.; Tam, G.; Wharton, S. Lead and Arsenic Uptake by Leafy Vegetables Grown on Contaminated Soils: Effects of Mineral and Organic Amendments. Water Air Soil Pollut. 2012, 224, 1-10. [CrossRef] [PubMed]

50. Shaheen, S.M.; Antoniadis, V.; Kwon, E.E.; Biswas, J.K.; Wang, H.; Ok, Y.S.; Rinklebe, J. Biosolids application affects the competitive sorption and lability of cadmium, copper, nickel, lead, and zinc in fluvial and calcareous soils. Environ. Geochem. Health 2017, 39, 1365-1379. [CrossRef] [PubMed]

51. Tang, X.; Li, X.; Liu, X.; Hashmi, M.Z.; Xu, J.; Brookes, P.C. Effects of inorganic and organic amendments on the uptake of lead and trace elements by Brassica chinensis grown in an acidic red soil. Chemosphere 2015, 119, 177-183. [CrossRef]

52. Commission Regulation (EC). No 1881/2006 setting maximum levels for certain contaminants in foodstuffs. Off. J. Eur. Union 2006, 49, L173/6.

53. Gaw, S.K.; Kim, N.D.; Northcott, G.L.; Wilkins, A.L.; Robinson, G. Uptake of $\Sigma$ DDT, Arsenic, Cadmium, Copper, and Lead by Lettuce and Radish Grown in Contaminated Horticultural Soils. J. Agric. Food Chem. 2008, 56, 6584-6593. [CrossRef] [PubMed]

54. Markert, B. Establishing of 'Reference Plant' for inorganic characterization of different plant species by chemical fingerprinting. Water Air Soil Pollut. 1992, 64, 533-538. [CrossRef]

55. Marschner, H.; Marschner, P. Marschner's Mineral Nutrition of Higher Plants, 3rd ed.; Elsevier: London, UK; Academic Press: Waltham, MA, USA, 2012; Chapter XV; 651p.

56. Atkinson, N.R.; Young, S.D.; Tye, A.M.; Breward, N.; Bailey, E.H. Does returning sites of historic peri-urban waste disposal to vegetable production pose a risk to human health?-A case study near Manchester, UK. Soil Use Manag. 2012, 28, 559-570. [CrossRef]

57. França, F.C.; Albuuerque, A.M.; Almeida, A.C.; Silveira, P.B.; Filho, C.A.; Hazin, C.A.; Honorato, E.V. Heavy metals deposited in the culture of lettuce (Lactuca sativa L.) by the influence of vehicular traffic in Pernambuco, Brazil. Food Chem. 2017, 215, 171-176. [CrossRef] [PubMed]

58. Zhao, J.; Lu, C.; Tariq, M.; Xiao, Q.; Zhang, W.; Huang, K.; Lu, Q.; Lin, K.; Liu, Z. The response and tolerance mechanisms of lettuce (Lactuca sativa L.) exposed to nickel in a spiked soil system. Chemosphere 2019, 222, 399-406. [CrossRef] [PubMed]

59. EFSA Panel on Contaminants in the Food Chain (CONTAM); Schrenk, D.; Bignami, M.; Bodin, L.; Chipman, J.K.; del Mazo, J.; Grasl-Kraupp, B.; Hogstrand, C.; Hoogenboom, L.; Leblanc, J.-C.; et al. Update of the risk assessment of nickel in food and drinking water. EFSA J. 2020, 18, e06268. [PubMed]

60. World Health Organization. GEMS/Food Regional Diets: Regional per Capita Consumption of Raw and Semi-Processed Agricultural Commodities/Prepared by the Global Environment Monitoring System/Food Contamination Monitoring and Assessment Programme (GEMS/Food), Rev. ed.; World Health Organization: Geneva, Switzerland, 2003.

61. Adamo, P.; Iavazzo, P.; Albanese, S.; Agrelli, D.; De Vivo, B.; Lima, A. Bioavailability and soil-to-plant transfer factors as indicators of potentially toxic element contamination in agricultural soils. Sci. Total Environ. 2014, 500-501, 11-22. [CrossRef]

62. EFSA Panel on Contaminants in the Food Chain (CONTAM). Scientific Opinion on the risks to public health related to the presence of chromium in food and drinking water. EFSA J. 2014, 12, 3595.

63. Scientific Committee on Food Opinion of the Scientific Committee on Food on the Tolerable Upper Intake Level of Zinc; European Commission, Health Consumer Protection Directorate-General: Brussels, Belgium, 2003.

64. Baldwin, K.R.; Shelton, J.E. Availability of heavy metals in compost-amended soil. Bioresour. Technol. 1999, 69, 1-14. [CrossRef]

65. Bashir, M.; Wang, X.; Naveed, M.; Mustafa, A.; Ashraf, S.; Samreen, T.; Nadeem, S.; Jamil, M. Biochar Mediated-Alleviation of Chromium Stress and Growth Improvement of Different Maize Cultivars in Tannery Polluted Soils. Int. J. Environ. Res. Public Health 2021, 18, 4461. [CrossRef] [PubMed]

66. Dala-Paula, B.M.; Custódio, F.B.; Knupp, E.A.; Palmieri, H.E.; Silva, J.B.B.; Glória, M.B.A. Cadmium, copper and lead levels in different cultivars of lettuce and soil from urban agriculture. Environ. Pollut. 2018, 242, 383-389. [CrossRef]

67. Khan, S.; Rehman, S.; Khan, A.Z.; Khan, M.A.; Shah, M.T. Soil and vegetables enrichment with heavy metals from geological sources in Gilgit, northern Pakistan. Ecotoxicol. Environ. Saf. 2010, 73, 1820-1827. [CrossRef]

68. Luo, C.; Liu, C.; Wang, Y.; Liu, X.; Li, F.; Zhang, G.; Li, X. Heavy metal contamination in soils and vegetables near an e-waste processing site, south China. J. Hazard. Mater. 2011, 186, 481-490. [CrossRef] [PubMed]

69. Wang, Y.; Qiao, M.; Liu, Y.; Zhu, Y. Health risk assessment of heavy metals in soils and vegetables from wastewater irrigated area, Beijing-Tianjin city cluster, China. J. Environ. Sci. 2012, 24, 690-698. [CrossRef]

70. Shu, W.; Ye, Z.; Lan, C.; Zhang, Z.; Wong, M. Lead, zinc and copper accumulation and tolerance in populations of Paspalum distichum and Cynodon dactylon. Environ. Pollut. 2002, 120, 445-453. [CrossRef] 